University of Nebraska - Lincoln

DigitalCommons@University of Nebraska - Lincoln

\title{
Late Cenozoic Climate Changes in China's Western Interior: A Review of Research on Lake Qinghai and Comparison with Other Records
}

Steven M. Colman

Large Lakes Observatory, University of Minnesota Duluth, MN 55812, USA

Shi-Yong Yua

Large Lakes Observatory, University of Minnesota Duluth, MN 55812, USA

Zhisheng Anc

Institute of Earth Environment, Chinese Academy of Sciences, Xi'an, PR China

Ji Shend

Nanjing Institute of Geography and Limnology, Chinese Academy of Sciences, Nanjing 210008, PR China

A.C.G. Henderson

Environmental Change Research Centre, Department of Geography, University College London, London, UK

Follow this and additional works at: https://digitalcommons.unl.edu/usgsstaffpub

Part of the Earth Sciences Commons

Colman, Steven M.; Yua, Shi-Yong; Anc, Zhisheng; Shend, Ji; and Henderson, A.C.G., "Late Cenozoic Climate Changes in China's Western Interior: A Review of Research on Lake Qinghai and Comparison with Other Records" (2007). USGS Staff -- Published Research. 278.

https://digitalcommons.unl.edu/usgsstaffpub/278

This Article is brought to you for free and open access by the US Geological Survey at DigitalCommons@University of Nebraska - Lincoln. It has been accepted for inclusion in USGS Staff -- Published Research by an authorized administrator of DigitalCommons@University of Nebraska - Lincoln. 


\title{
Late Cenozoic climate changes in China's western interior: a review of research on Lake Qinghai and comparison with other records
}

\author{
Steven M. Colman ${ }^{\mathrm{a}, \mathrm{b}, *}$, Shi-Yong Yu ${ }^{\mathrm{a}}$, Zhisheng $\mathrm{An}^{\mathrm{c}}$, Ji Shen ${ }^{\mathrm{d}}$, A.C.G. Henderson ${ }^{\mathrm{e}}$ \\ ${ }^{a}$ Large Lakes Observatory, University of Minnesota Duluth, MN 55812, USA \\ ${ }^{\mathrm{b}}$ Department of Geological Sciences, University of Minnesota Duluth, MN 55812, USA \\ ${ }^{\mathrm{c}}$ Institute of Earth Environment, Chinese Academy of Sciences, Xi'an, PR China \\ ${ }^{\mathrm{d}}$ Nanjing Institute of Geography and Limnology, Chinese Academy of Sciences, Nanjing 210008, PR China \\ ${ }^{\mathrm{e}}$ Environmental Change Research Centre, Department of Geography, University College London, London, UK
}

Received 15 August 2006; received in revised form 1 May 2007; accepted 14 May 2007

\begin{abstract}
We review Late Cenozoic climate and environment changes in the western interior of China with an emphasis on lacustrine records from Lake Qinghai. Widespread deposition of red clay in the marginal basins of the Tibetan Plateau indicates that the Asian monsoon system was initially established by $\sim 8 \mathrm{Ma}$, when the plateau reached a threshold altitude. Subsequent strengthening of the winter monsoon, along with the establishment of the Northern Hemisphere ice sheets, reflects a long-term trend of global cooling. The few cores from the Tibetan Plateau that reach back a million years suggest that they record the mid-Pleistocene transition from glacial cycles dominated by $41 \mathrm{ka}$ cycles to those dominated by 100 ka cycles.

During Terminations I and II, strengthening of the summer monsoon in China's interior was delayed compared with sea level and insolation records, and it did not reach the western Tibetan Plateau and the Tarim Basin. Lacustrine carbonate $\delta^{18} \mathrm{O}$ records reveal no climatic anomaly during MIS3, so that high terraces interpreted as evidence for extremely high lake levels during MIS3 remain an enigma. Following the Last Glacial Maximum (LSM), several lines of evidence from Lake Qinghai and elsewhere point to an initial warming of regional climate about $14500 \mathrm{cal}$ yr BP, which was followed by a brief cold reversal, possibly corresponding to the Younger Dryas event in the North Atlantic region. Maximum warming occurred about $10000 \mathrm{cal}$ yr BP, accompanied by increased monsoon precipitation in the eastern Tibetan Plateau. Superimposed on this general pattern are small-amplitude, centennial-scale oscillations during the Holocene. Warmer than present climate conditions terminated about $4000 \mathrm{cal} \mathrm{yr} \mathrm{BP.} \mathrm{Progressive} \mathrm{lowering} \mathrm{of} \mathrm{the} \mathrm{water} \mathrm{level} \mathrm{in}$ Lake Qinghai during the last half century is mainly a result of negative precipitation-evaporation balance within the context of global warming.
\end{abstract}

(C) 2007 Published by Elsevier Ltd.

\section{Introduction}

The dryland ecosystem on the northern Tibetan Plateau (Fig. 1A) is vulnerable to climate changes and human impacts. Degradation of grasslands, contraction of lakes, and desertification have become major environmental problems in recent years, affecting socio-economic development in the region. Restoring these lands or reversing

\footnotetext{
*Corresponding author. Large Lakes Observatory, 2205 E. 5th St., University of Minnesota Duluth, MN 55812, USA. Tel.: + 12187266723 ; fax: +12187266979 .

E-mail address: scolman@d.umn.edu (S.M. Colman).
}

these processes requires knowledge about the baseline conditions of the drylands and the dynamics of landscape change, particularly during past interglacials when climate boundary conditions were similar to the present. Studying Late Cenozoic climate changes on the Tibetan Plateau also is crucial for understanding the complex interaction among the atmosphere, lithosphere, hydrosphere, cryosphere, and biosphere of the Earth system on a longer time scale. Long, undisturbed lacustrine sediment sequences are important for addressing these questions. Previous studies reveal that sediment cores from Lake Qinghai contained abundant information about regional environmental history at various time scales. Because most of these results appear 

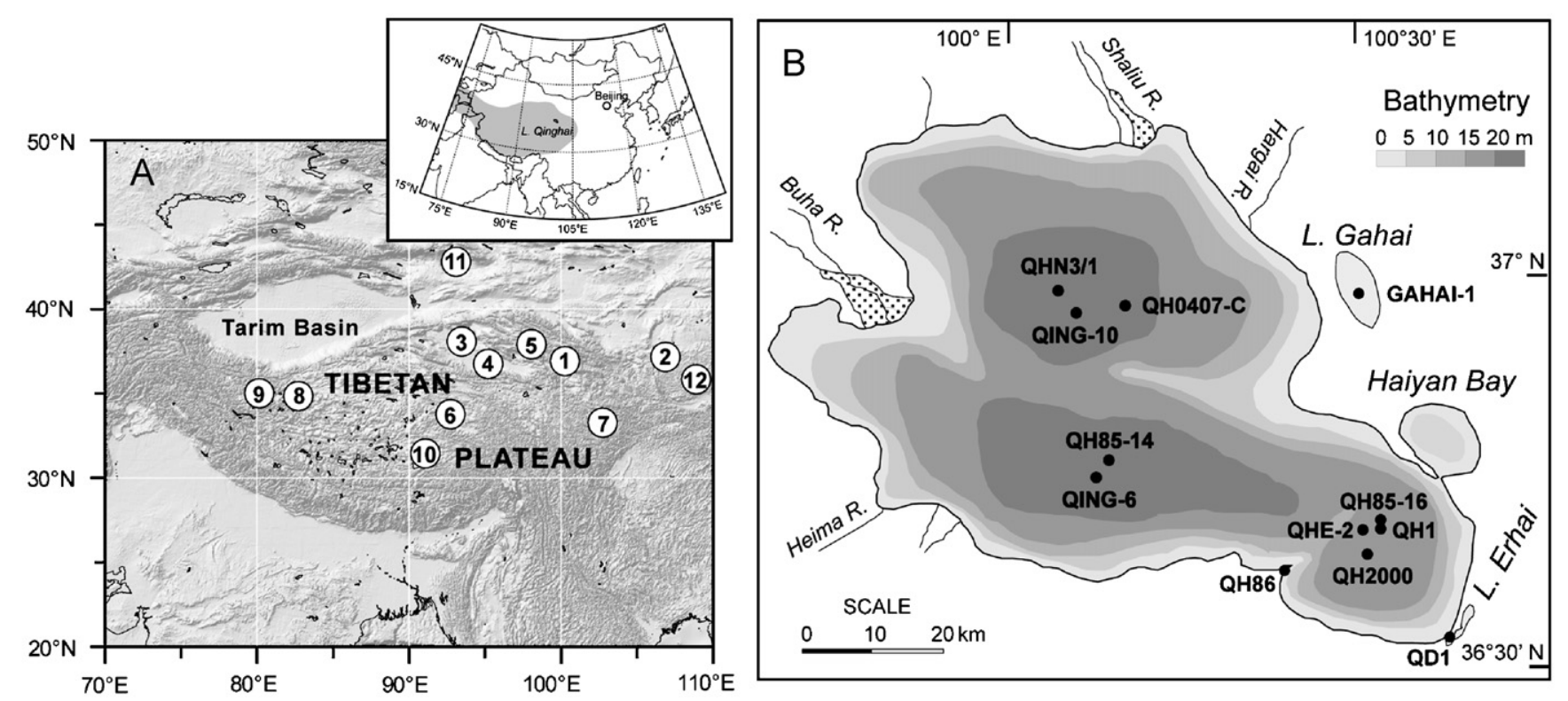

Fig. 1. (A) Relief of the western interior of China; numbered circles indicate sites discussed in the text. 1. Lake Qinghai; 2. Xifeng loess site; 3. Qarhan Playa; 4. Kunteyi Playa; 5. Dunde Ice Core; 6. Lake Co Ngoin; 7. Zoige Basin; 8. Guliya Ice Core; 9. Lake Tianshuihai; 10. Lake Man Co; 11. Lake Balikun; 12. Luochuan loess site. (B) Bathymetry of Lake Qinghai. Solid dots show the location of cores discussed in the text.

in Chinese-language journals, they are not accessible to the international community. In addition, future studies of drill cores from the Lake Qinghai Drilling Project, jointly funded by the Chinese Academy of Sciences (CAS) and the International Continental Drilling Program (ICDP), require background information about previous studies of climate and environment changes in this area. Hence, this review of paleoenvironmental studies was undertaken before the Lake Qinghai Drilling Project retrieved its cores from Lake Qinghai in late 2005.

The importance of Lake Qinghai sediment records for understanding past global changes has been increasingly recognized since the 1870s (cf. Chen et al., 1990), due to its unique geographical location (Fig. 1A). Preliminary geological and geomorphologic mapping in the lake area were performed during the first half of the 20th century (Shi et al., 1958; Chen et al., 1964). However, limnological studies using modern techniques did not start until the 1960s, when fundamental data on lake biology, water chemistry, and hydrology were first obtained during a multi-disciplinary expedition (Lanzhou Institute of Geology and Chinese Academy of Sciences (LZIG-CAS), 1979). Yang and Jiang (1965) examined Quaternary vegetation history by analyzing pollen assemblages of a 210-m-long drill core (QH5) on the Erlangjian terrace (Fig. 1B). Interest continued to increase in the 1980s. Approximately 80 cores were drilled around the lake by the Qinghai Geological and Mineral Resource Administration. Two of these cores (DH-54 and DH-64) reached depths of 500 and $300 \mathrm{~m}$ below the sediment surface, respectively, and thus provide long potential records of Quaternary climate changes. Coordinated by the Institute for Salt Lake Studies, CAS, a Sino-Swiss-Australian cooperative project was implemented in 1984, aiming to elucidate the recent climate history of the area. In 1987, a 155-m-long drill core (QH86) from the Erlangjian terrace (Fig. 1B), along with three short piston cores, numbed QH85-14, QH85-15, and QH85-16, from the southern sub-basin of the lake, were recovered. ${ }^{210} \mathrm{~Pb}$ and ${ }^{137} \mathrm{Cs}$ dating (Huang and Sun, 1989) of these piston cores, along with a variety of other analyses, including pollen (Du et al., 1989; Kong et al., 1990; Shan et al., 1993), carbon (Kelts et al., 1989; Huang and Meng, 1991), elemental and isotope geochemistry (Zhang et al., 1989a, b, 1994; Lister et al., 1991; Sun et al., 1991) have been carried out. These proxies reveal Lateglacial to Holocene changes in lake hydrology and catchment environment associated with the advance and retreat of the Asian summer monsoon front (Wang and Shi, 1992; Wei and Gasse, 1999; Yu and Kelts, 2002).

The foci of ongoing paleolimnological studies are on high-resolution changes in lake hydrology and regional climate, based on multiple stratigraphic analyses of short cores, i.e. QING-6, QHE-2, QING-10, QHN3/1, QH0407C, and GAHAI-1 (Fig. 1B). A group from the University of Lanzhou and University College London (Guo et al., 2002a; Henderson et al., 2003; Shi et al., 2003; Zhang et al., 2003; Henderson, 2004), and one from the Institute of Geography and Limnology, CAS, (Shen et al., 2001; Liu et al., 2002; Zhang et al., 2002a, b, 2004; Liu et al., 2003a, b, c; Shen et al., 2005) have played leading roles in this wave of investigation. However, systematic studies of modern conditions and limnological processes are rare (Chinese Academy of Science Lanzhou (CAS-LZ), Research Center for Resource and Environment of Western China, Chinese Academy of Sciences (RCREWC-CAS), 1994). Numerical models have been used to try to understand the hydrological and chemical evolution of the lake under various scenarios of climate forcing (Qin and Huang, 1998a, b; Yan 
et al., 2002), although few data exist to constrain such models.

Here we compile and synthesize previously published results of paleolimnological studies of Lake Qinghai. We then compare paleoclimate records from the Tibetan Plateau and nearby areas for four time intervals (Late Cenozoic, the Last Interglacial, Marine Isotope Stage (MIS) 3, and the Postglacial), three of which are currently represented by data from Lake Qinghai, in an effort to synthesize paleoclimate information from the Tibetan Plateau.

\section{Environmental setting}

\subsection{Neogene climate history}

The inception and subsequent intensification of the Asian monsoon have long been ascribed to the upward/ outward growth of the Tibetan Plateau (Ruddiman et al., 1989; Molnar et al., 1993; An et al., 2001; Li et al., 2001; Liu and Yin, 2002), within the context of global cooling during the Neogene (Maslin et al., 1998; Hay et al., 2002; Gupta et al., 2004). Although magneto-stratigraphy of loess-soil sequences and other sediment records from surrounding areas provide an a priori constraint on the uplift history of the Tibetan Plateau (Quade et al., 1989; Rea et al., 1998; An et al., 2001; Dettman et al., 2003), the timing and mechanisms have been the subject of debate (Harrison et al., 1992; Coleman and Hodges, 1995; Chung et al., 1998). Independent geological evidence reveals that a modest uplift in the eastern Tibetan Plateau began at $\sim 40 \mathrm{Ma}$ (Harrison et al., 1992; Chung et al., 1998), as a result of the Indio-Asian collision. However, persistent dry conditions following the Paleocene-Eocene thermal maximum in Qaidam Basin (Wang et al., 1999) suggest that the plateau did not reach an elevation high enough to modify the prevailing atmospheric circulation pattern.

Extensive uplift about $22 \mathrm{Ma}$ is indicated by widespread failures of the Paleogene planation surfaces and increased sedimentation rates in the neighboring basins (Zhang et al., 2001). This large-scale surface uplift, along with substantial retreat of the Paratethys Sea (Ramstein et al., 1997), is believed to have initiated desertification of the Asian interior (Guo et al., 2002b). A weak Asian summer monsoon circulation may have been established when the plateau reached a threshold elevation of $\sim 1500$ m (Ruddiman and Kutzbach, 1989). Palynological evidence from Qaidam Basin (Wang et al., 1999) and Linxia Basin (Ma et al., 1998) indicate that dry conditions were not fully established in the western interior of China until $\sim 15 \mathrm{Ma}$. This signals the initial cooling of the Late Cenozoic (Zhou and Zhu, 2001). Superimposed upon this general trend were two drying episodes that occurred at about 14 and $8 \mathrm{Ma}$ (Guo et al., 2002b), the first of which can be correlated to the initial growth of the Antarctic Ice Sheet and probably associated with internal feedbacks in the climate system. A wealth of evidence suggest that the latter can be attributed to the Tibetan uplift (An, 2000), which raised the plateau surface to its present altitude and thus gave rise to the modern Asian summer monsoon. Widespread red clay deposition beginning $\sim 8 \mathrm{Ma}$ in the marginal basins of the Tibetan Plateau (An, 2000) and increased dust transport to the North Pacific (Rea et al., 1998) indicate that the Asian winter monsoon was also established at that time. Superimposed upon a global cooling trend was the gradual strengthening of the Asian winter monsoon from $3.6 \mathrm{Ma}$ onward, thereby leading to thick loess deposition along the margin of deserts and gobis (An, 2000) and dust deposition in the North Pacific (Rea et al., 1998). In this context, Lake Qinghai lies at the transition from the arid to the semi-arid zones, where the climate is controlled by the Asian summer monsoon, the Asian winter monsoon, and the westerlies. It is thus well suited to monitor changes in Late Cenozoic climate.

\subsection{Geomorphologic and tectonic backgrounds}

Lake Qinghai $\left(36^{\circ} 15^{\prime}-38^{\circ} 20^{\prime} \mathrm{N}, \quad 97^{\circ} 50^{\prime}-101^{\circ} 20^{\prime} \mathrm{E}\right)$ is situated on the northeastern Tibetan Plateau, and is the largest inland water body of China by surface area. The lake is developed within a basin surrounded by three mountain ranges (Bian et al., 2000): Datong Mts to the north, Riyue Mts to the east, and Qinghai Nanshan Mts to the south. These mountains, with general elevations above $4000 \mathrm{~m}$, account for ca $70 \%$ of the drainage area. The lake basin is open to the west, from where it receives its major runoff from the Buha River, which, along with other major rivers, have created fluvial plains and deltas in the western and northern shores. Dunes and beach ridges are common along the eastern shore, reflecting a prevailing westerly wind pattern. Fault escarpments and terraces are extensively developed along the southern shore, where faulting and block tilting are still active. Glacial and periglacial landforms can be found on Qinghai Nanshan Mts (Porter et al., 2001), whereas small modern glaciers only occur on mountains in the upper Buha River drainage basin.

The Late Cenozoic tectonic evolution of the region represents the history of growth of northeastern margin of the Tibetan Plateau (Molnar et al., 1993). A northwestdipping thrust fault is present along southern range-front of the Qinghai Nanshan Mts The mountain range is thus a tectonic ramp that thrusts southward over the Gonghe basin. The Riyue Shan fault zone consists of a high-angle, right-lateral strike-slip fault in the middle of the range and a west-dipping, low-angle thrust fault along the eastern range-front of the mountain. Therefore, Lake Qinghai is basically a piggyback basin behind the thrust ramps to the south and west.

The onset of Cenozoic tectonics in the Lake Qinghai region is believed to be either Late Miocene or early Pliocene along the Qinghai Nanshan fault, which caused uplift of the Qinghai Nanshan Mts (Metivier et al., 1998), thereby separating Lake Qinghai from the Gonghe basin. The uplift of the Riyue Shan Mts intersects the NWW- 
trending Qinghai Nanshan Mts near Lake Qinghai during the late Pleistocene (Yuan et al., 1990). This uplift eventually blocked the river system that used to drain Lake Qinghai to the east, and isolated Lake Qinghai to form the closed intra-mountain piggyback basin that we see today.

\subsection{Climate and vegetation}

Lake Qinghai lies in the transition from semi-arid to arid zones, where mean annual precipitation is $\sim 360 \mathrm{~mm}$ (CASLZ and RCREWC-CAS, 1994), decreasing along a gradient from surrounding mountains $(\sim 400 \mathrm{~mm})$ to the lake area (e.g. $\sim 220 \mathrm{~mm}$ on Mt Haixin). The annual precipitation also shows temporal variability and most $(60 \%)$ falls in summer months (June-August). With much sunshine $(3640 \mathrm{~h} / \mathrm{a})$ and high insolation $\left(\sim 6.5 \times 10^{15} \mathrm{~J} /\right.$ $\mathrm{m}^{2} \mathrm{a}$ ), annual mean evaporation is $\sim 800 \mathrm{~mm}$. It decreases from the lake area $(\sim 1000 \mathrm{~mm})$ to surrounding mountains $(\sim 310 \mathrm{~mm})$. More than $60 \%$ of the evaporation occurs in summer. Annual mean temperature is ca $-0.7^{\circ} \mathrm{C}$ and exhibits remarkably high seasonality, varying from ca $-11^{\circ} \mathrm{C}$ in winter to ca $12{ }^{\circ} \mathrm{C}$ in summer. Winds blow onshore at daytime and offshore at night with an average speed of $4-6 \mathrm{~m} / \mathrm{s}$.

The lake has a drainage area of $29660 \mathrm{~km}^{2}$, which is mainly vegetated by montane shrubs, alpine steppes, and high-alpine meadows. The vegetation shows a distinct vertical zonation (Chen and Peng, 1993). Forests are rare and scattered. Major tree species are Sabina przewalskii, Sabina vulgaris, Salix oritrepha, Picea crassifolia, Populus cathayna, and Populus simonii. Shrubs, dominated by Caragana jubta, Potentilia fruticosa, Potentilia glabra, Myricaria sgamosa, Hippophae neurocarpa, and Cotoneaster acutifolius, appear locally and mainly colonize on the base of the southern slopes. Alpine steppes, composed of Achnatherum splandens, Kobresia pygmaea, Kobresia humulis, Kobresia bellardii, Kobresia capillifolia, Leontopodium nanum, Androsacatapete, Thylacospermum caespitosum, Stipa purea, S. breviflora, Artemisia ordosis, Agropyron desertorum, Carex stenophylla, Oxytropis falcate, and Poa sinoglauce, frequently occur between 3200 and $4500 \mathrm{~m}$. Desert steppes, including mainly Artemisia sphaerocephala, Cxytropis aciphalla, Agropyrom cristatum, Ephedra intermedia, and Kobresia robusta, occur rarely. Wetland communities have low species diversity, and the major species are Triglochin palustre, Triglochin maritimum, Blysmus sinocompressus, Carex spp., and Potentilia acaulis. Aquatic plants are rare: only two species, Potamogeton pectinatus and Ruppia maritime, as well as a few emergent sedge species are found in quiet waters near the shore (Chen, 1987a, b).

Human impact on modern vegetation of the area, at least in relation to preservation of pollen spectra, are thought to be minimal. Archeological sites in the area are rare, and no late Neolithic sites occur around the margins of Lake Qinghai (Madsen et al., 2006). Forested areas are uncommon and scattered, so human deforestation is not prevalent. Even today, the Lake Qinghai area is remote and sparsely populated.

\subsection{Lake hydrology and water chemistry}

The lake basin is located at $3194 \mathrm{~m}$ above sea level (asl), with a surface water area of $4400 \mathrm{~km}^{2}$ and volume of $7.16 \times 10^{10} \mathrm{~m}^{3}$. Five large rivers seasonally discharge to the lake basin with annul runoff of $\sim 1.34 \times 10^{9} \mathrm{~m}^{3}$ (Wang, 2003). Annual sand discharge to the lake is $4.98 \times 10^{5} \mathrm{~T}$. The Buha River, with a watershed of $14337 \mathrm{~km}^{2}$, is the largest river both by runoff (50\% of the total) and sand discharge ( $70 \%$ of the total). Meltwater from surrounding mountain glaciers accounts for only $0.3 \%$ of the total runoff. The hydrological residence time of the lake was estimated as 33 years (Lister et al., 1991). The lakebed is generally flat, with an average water depth of $21 \mathrm{~m}$. The lake is divided into two nearly equally sub-basins by a NNW-trending horst, from which an island (Mt Haixin) emerges. Maximum depth $(27 \mathrm{~m})$ occurs in the southern sub-basin (12 km south of Mt Haixin). Several minor fault scarps also can be found in the lake basin.

The lake water is brackish to saline with an average salinity of $14.1 \mathrm{~g} / \mathrm{L}$ and a $\mathrm{pH}$ of 9.2. Electrical conductivity is $20.63 \mathrm{~ms} / \mathrm{cm}$. Lake water $\delta D$ is $10.0 \%$ (V-SMOW), and $\delta^{18} \mathrm{O}$ is $1.97 \%$ (V-SMOW), values that are much higher than those of local meteoric precipitation and thus indicate that the lake is hydrologically closed, and evaporative (Zhang et al., 1994). In summer, weak thermal stratification develops, with an epilimnion of $12-15^{\circ} \mathrm{C}$, and a hypolimnion of $6^{\circ} \mathrm{C}$ (Williams, 1991). The surface water is usually saturated in summer with respect to its carbonate minerals, generating a continuous rain of aragonite. The lake surface is frozen during winter months (December-March) with a maximum ice thickness of $0.8 \mathrm{~m}$.

\section{Paleolimnological records of Lake Qinghai at different time scales}

\subsection{Potential record from long drill cores}

Oxygen isotope records of marine cores reveal that the Earth's climate system has experienced significant changes during the Late Cenozoic, characterized by a gradual shift from an ice-free mode to glacial conditions after $\sim 3.6 \mathrm{Ma}$ (Zachos et al., 2001). Northern Hemisphere glaciation apparently began at about 2.7 Ma (cf. Haug et al., 2005). A leading hypothesis for this transition is the tectonically induced closure of Pacific-Atlantic seaways (Haug and Tiedemann, 1998; Cane and Molnar, 2001), which in turn caused the reorganization of ocean circulation. In contrast to oceanic changes, extensive uplift of mid-latitude mountains, particularly the Tibetan Plateau, also has been suggested as playing a vital role in triggering global climate changes through physical and weathering processes (Ruddiman and Kutzbach, 1989; Raymo and Ruddiman, 1992; 
France-Lanord and Derry, 1997). Therefore, dating this change in terrestrial records, especially those on or close to the Tibetan Plateau, is important for providing evidence for the causal relationship between tectonic uplift and climate changes. Although evidence has been accumulating from areas surrounding the plateau (Quade et al., 1989; Prell and Kutzbach, 1992; Rea et al., 1998; An et al., 2001), long, high-quality records from the Tibetan Plateau itself are lacking.

Lacustrine sediments from large lakes hold one of the keys to understanding Late Cenozoic climate changes in Asian inland (e.g. Colman et al., 1995; Colman, 1996; Williams et al., 1997). Previous drilling from the Erlangjian terrace (a spit prograding into Lake Qinghai) reveals that the lake sediments may have a higher temporal resolution (Yuan et al., 1990) than the red clay-loess-soil sequences. Recent geophysical surveys (An et al., 2006) reveal that the thickness of lacustrine sediments in the lake exceeds $700 \mathrm{~m}$. The age of the basal lacustrine sediments is estimated to be late Miocene (Yuan et al., 1990). Detailed chronological, sedimentological, geochemical, and biostratigraphic analyses of long drill cores from current and ongoing Lake Qinghai drilling projects have the potential to shed new light on the timing of Late Cenozoic tecto-climate events and the dynamics of the Asian monsoon system during the last eight million years.

\subsection{The $Q H 86$ record}

\subsubsection{Stratigraphy and chronology}

Core QH86, drilled from the Erlangjian terrace on the southern shore in 1987, is the longest sediment sequence of Lake Qinghai to date (Yuan et al., 1990). The upper $80 \mathrm{~m}$ of the core consists of continuous lacustrine silty clay interrupted rarely by coarse sand and silt. This stratigraphy reveals a generally stable sedimentary environment within the lake basin, interspersed with episodic fluctuations of lake level. The record below $80 \mathrm{~m}$ reveals that the lake basin was shallow, but not subaerially exposed during previous glaciations, as indicated by a thick layer of fine sandy sediments interbedded with silt and gravel between 127 and $140 \mathrm{~m}$. The Brunhes/Matuyama (B/M) paleomagnetic polarity boundary $(\sim 0.8 \mathrm{Ma})$ occurs at $120 \mathrm{~m}$, yielding an average sediment accumulation rate of about $0.16 \mathrm{~mm} / \mathrm{a}$. Assuming a constant accumulation rate, full lacustrine conditions (at $\sim 80 \mathrm{~m}$ ) were established in the lake basin after $\sim 0.5 \mathrm{Ma}$ (Yuan et al., 1990). However, Ruppia seeds were found at $\sim 96.5 \mathrm{~m}$, and freshwater algae account for $69 \%$ of the total pollen at $\sim 120 \mathrm{~m}$ (Shan et al., 1993), implying that episodic lacustrine conditions occurred much earlier. Twelve uranium-series ages on authigenic carbonates were obtained by Shan et al. (1993). Although no details on the ages were given, they lead to an age-depth relationship for the upper $80 \mathrm{~m}$ of the core of: Age $=4234 \times$ Depth +11414 .

\subsubsection{Pollen assemblages}

Pollen analyses of 90 samples from the upper $80 \mathrm{~m}$ of cores from QH86 were performed by Shan et al. (1993). Pollen grains are poorly preserved below this level, and only a few grains were found. The relative abundances of major taxa in this core are presented in Fig. 2. Pollen assemblages are dominated by dwarf shrubs and herbs, which account for ca $80 \%$ of the total palynomorphs and mainly include Ephedra, Nitaria, Artemisia and Chenopodiaceae. Abundances of arboreal pollen, including Abies, Picea, Pinus, Cedrus, Tsuga, Betula, Corylus, Alnus, Ulmus, Juglans, Tilia, and Rhus, are very low, generally less than $20 \%$ of the total. Wetland and aquatic herbs, including Compositae, Umbelliferae, Polygonaceae, Cyperaceae, Typha, Potamogeton, and Ruppia, are very rare. Seven local pollen zones (Fig. 2) were defined (Shan et al.,

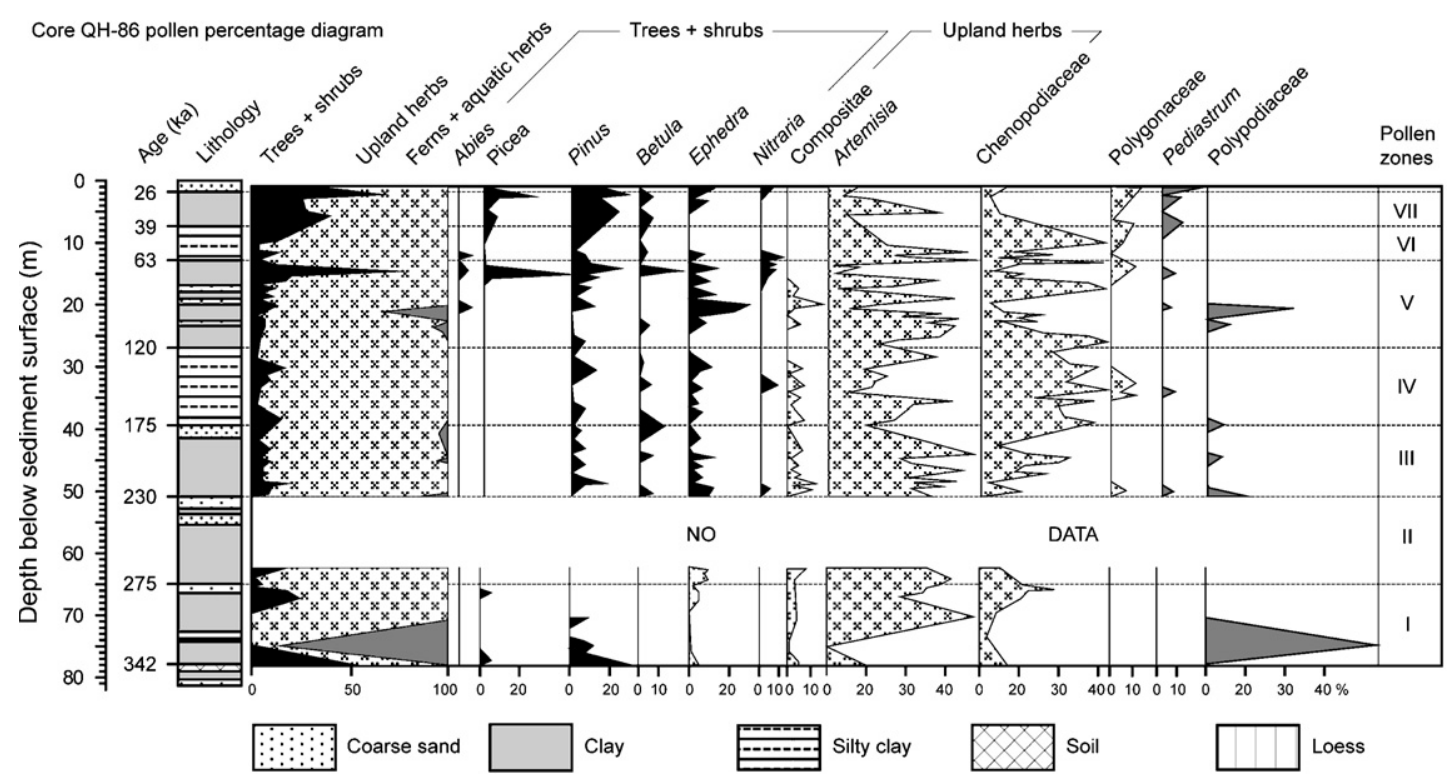

Fig. 2. Core QH86 pollen percentage diagram (after Shan et al., 1993). Only major taxa are shown. 
1993), and the original interpretations are summarized below. The age of major pollen zone boundaries was calculated from the age-depth model described above.

Zone I $(77.93-62.21 \mathrm{~m} ; 342-275 \mathrm{ka})$ : this zone is dominated by dryland herbs such as Artemisia and Chenopodiaceae. Tree pollen only account for $14 \%$, with a maximum occurring at around $78 \mathrm{~m}$. High values of Polypodiaceae spores occur around $75 \mathrm{~m}$, indicating a period of wetland expansion possibly associated with lakelevel rise.

Zone II (62.21-51.81 m; 275-230 ka): pollen concentrations are very low, and only a few Pinus and Ephedra pollen grains were found. These low pollen concentrations most likely indicate a period of extremely low lake levels and sedimentary conditions not conducive to pollen preservation.

Zone III (51.81-38.60; 230-175 ka): dryland herbs, such as Artemisia, dominated the alpine meadow landscape. Abundances of tree pollen decreased to $8 \%$. Polypodiaceae and Pediastrum occurred episodically, indicating a period of variable lake level.

Zone IV (38.60-25.71 m; 175-120 ka): tree pollen continued to decrease. Fern spores and aquatic pollen are very rare. Artemisia pollen decreased substantially, concurrent with the maximum abundance of Chenopodiaceae pollen. This pollen assemblage indicates a transition from alpine meadow to an alpine steppe landscape associated with increasing dry conditions during the penultimate glaciation.

Zone V (25.71-12.25 m; 120-63 ka): pollen assemblages are still dominated by Artemisia and Chenopodiacea, but tree pollen, including Picea, Betula, and Pinus, increased gradually and reached $15 \%$. This pollen assemblage indicates a landscape of alpine steppe with scattered mixed forests of coniferous and broad-leaved trees. Polypodiaceae and Pediastrum occurred again at about $25 \mathrm{~m}$ with an abundance reaching 39\%, reflecting a substantial expansion of wetland, most likely associate with lake-level rise at about $95 \mathrm{ka}$.

Zone VI (12.25-6.52 m; 63-39 ka): this zone is marked by a gradual decrease in tree pollen. Abundances of Artemisia pollen increased first, followed by Chenopodiaceae. Such a succession from a landscape of alpine steppe with scattered mixed forests to an alpine steppe indicates increasingly dry conditions during MIS 4.

Zone VII $(6.52-3.50 \mathrm{~m} ; 39-26 \mathrm{ka})$ : this zone is marked by considerable increases in tree pollen, along with a modest rise in the abundance of aquatic herbs and ferns. Abundances of Artemisia and Chenopodiaceae pollen decreased substantially. This pollen assemblage points to landscapes of mixed forests with coniferous and broadleaved trees, suggesting warmer and wetter than present conditions during MIS 3 (but see Section 4.2.2).

\subsection{The $Q H 85$ and $Q H 2000$ records}

\subsubsection{Stratigraphy, chronology, and sedimentation rates}

Preliminary geophysical investigations of the lake floor topography and sediments were conducted during the Sino-Swiss-Australian project, using high-resolution $(3.5 \mathrm{kHz})$ seismic-reflection techniques and coring. Seismic profiles reveal a pronouncedly layered feature of sediments and two units can be identified (Kelts et al., 1989). The $H$ series is 6-7-m-thick and thins gradually towards the shore. This unit appears to represent continuous and undisturbed lacustrine sediments (Fig. 3). A strong reflection (from the $Q$-reflector) could be correlated with the top of a yellowish silty sandy layer at Sites QH85-14B and QH85-16A. This

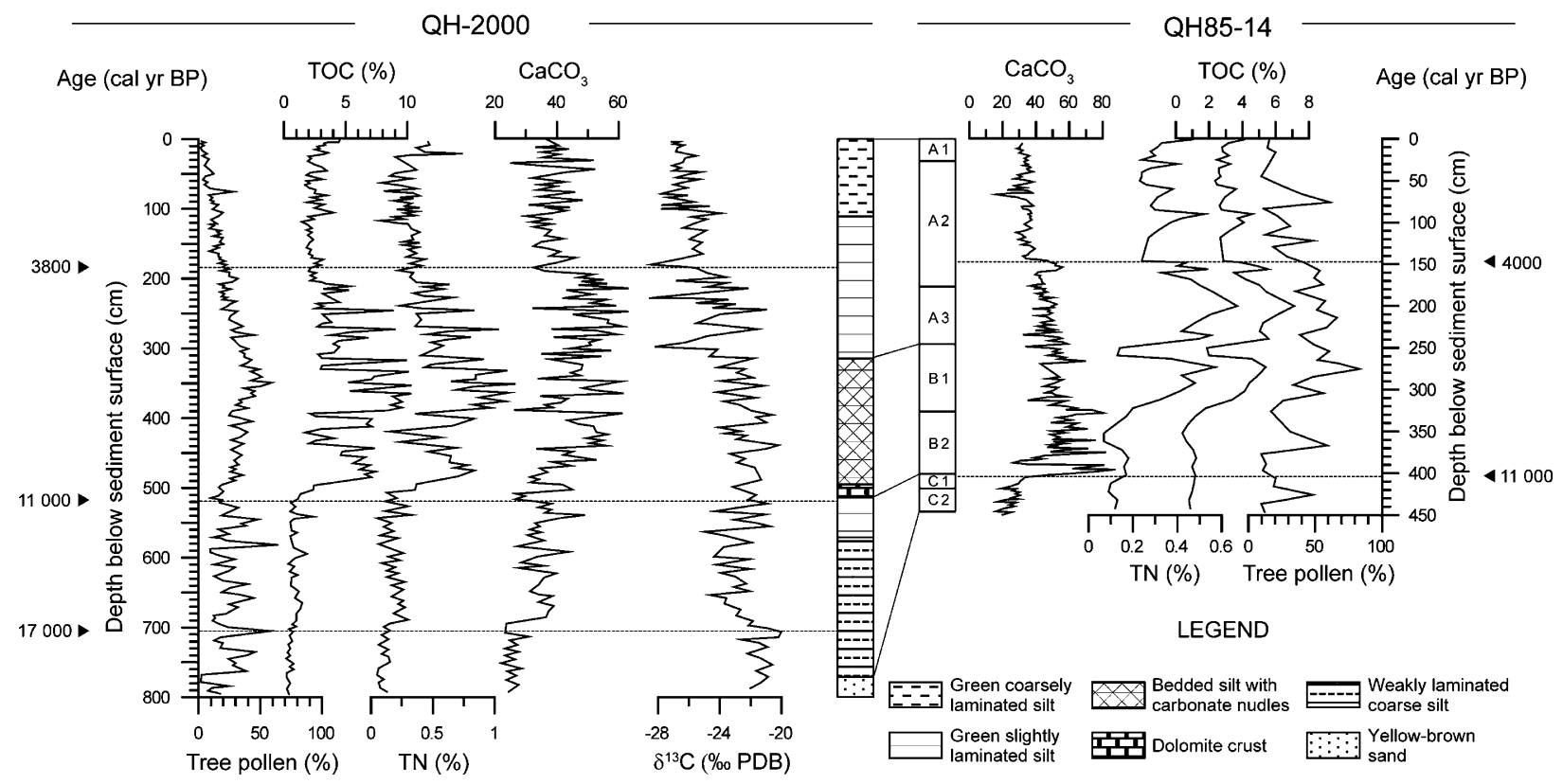

Fig. 3. Correlation of total organic carbon (TOC), total nitrogen (TN), carbonate, arboreal pollen, and organic carbon isotope records between Cores QH2000 (Shen et al., 2005) and QH85-14 (Du et al., 1989; Kelts et al., 1989; Huang and Meng, 1991). Dashed lines indicate boundaries of major changes. 
layer is present in the entire basin and probably indicates a period of extremely low lake level. This inference is supported by the stratigraphy of Core QH2000 (Shen et al., 2005), where massive yellow-brownish sand occurs at $\sim 7.7 \mathrm{~m}$ (Fig. 3). Extrapolations of radiocarbon chronologies for these cores suggest that the upper part of this layer was deposited at $\sim 19000 \mathrm{cal} \mathrm{yr} \mathrm{BP}$ (Table 1; Fig. 3), approximately the Last Glacial Maximum (LGM). Satellite images show an underwater beach ridge in the eastern part of the lake and a 6-km-long underwater channel in the western part (Yuan et al., 1990), which were interpreted to have developed during the LGM. These findings imply that the lake level was much lowered during the LGM, presumably controlled by a dry, cold climate (Lister et al., 1991; Shen et al., 2005).

Dating sediment cores from Lake Qinghai is problematic because of potential hard water effects, which have been a great challenge to paleolimnological studies. Terrigenous plant macrofossils in the almost treeless watershed are rare, and thus bulk organic matter (OM) usually is used for radiocarbon dating. However, OM may have been reworked and delivered to the lake from various pre-aged sources by river and groundwater discharges. Linearly fitting the calibrated radiocarbon ages of OM to depth in cores (Table 1) gives a sediment-surface intercept of 1039 years for Core QH2000 (Shen et al., 2005), 439 years for QH85-16A (Zhang et al., 1994), and 1100 years for Core QH85-14B (Kelts et al., 1989). These core-top apparent ages could be ascribed to a hard-water effect or reservoir age inherited from the catchment. A radiocarbon age of $661 \pm 32 \mathrm{yr}$ BP for dissolved organic carbon (DOC) was reported by Henderson (2004). The finite age of modern lake water DOC again indicate the inputs of older OM by river and groundwater discharges. In contrast, the dissolved inorganic carbon (DIC) in lake water is dated to be post-1950 (Henderson, 2004), indicating that ${ }^{14} \mathrm{C}$-rich DIC added from the post-nuclear testing atmosphere is offset by the pre-aged DIC derived from catchment weathering. Another complication is that radiocarbon ages of carbonates from some short cores are about 1000 years older than those of OM samples from the same horizon (Henderson, 2004). This may be due to the introduction of detrital carbonates from the catchment. If so, using stable isotopes of lacustrine carbonate as a climate proxy would also be problematic.

Sedimentation rates in the lake subbasins during the last 200 years have been well constrained by measuring activities of ${ }^{210} \mathrm{~Pb}$ and ${ }^{137} \mathrm{Cs}$ (Huang and Sun, 1989; Zhang, 2003; Henderson, 2004; Xu et al., 2006a). Sedimentary ${ }^{137} \mathrm{Cs}$ signals are exceptionally strong in these cores, and the post-bomb maximum of 1963 is clear. A rapid increase in sedimentation rate, along with high values of magnetic susceptibility after 1952 in Core QH2000 suggests strong catchment erosion associated with overgrazing and extensive land reclamation (Zhang et al., 2002a, b). Sedimentation rates show high spatial variability (Table 2), which is consistent with preliminary sediment trap studies (CAS-LZ and RCREWC-CAS, 1994). High values occur in the

Table 1

Radiocarbon ages of Cores QH85-14B (Kelts et al., 1989), QH85-16A (Zhang et al., 1989b), and QH2000 (Shen et al., 2005), Lake Qinghai, China

\begin{tabular}{|c|c|c|c|c|c|}
\hline Depth $(\mathrm{cm})$ & Lab. ID & Materials dated & $\delta^{13} \mathrm{C}(\%$ PDB $)$ & Radiocarbon age (yr BP) & $2 \sigma$ calibrated age (yr BP) \\
\hline \multicolumn{6}{|c|}{ Core QH85-14B } \\
\hline $47.5-49$ & - & Algal threads & - & $1780 \pm 23$ & $1820-1610$ \\
\hline $339.5-341$ & - & Ruppia seeds & - & $8400 \pm 130$ & $9600-9000$ \\
\hline $382-383.5$ & - & Ruppia seeds & - & $9730 \pm 130$ & $11650-10650$ \\
\hline $387-395$ & - & Ruppia seeds & - & $9870 \pm 170$ & $12050-10750$ \\
\hline $438-440$ & - & Ruppia seeds & - & $10900 \pm 250$ & $13350-12150$ \\
\hline \multicolumn{6}{|c|}{ Core QH85-16A } \\
\hline $14-21$ & ANU-6020 & Organic matter & - & $660 \pm 140$ & $950-400$ \\
\hline $61-70$ & ANU-6021 & Organic matter & - & $2280 \pm 100$ & $2700-2000$ \\
\hline $151.5-161.5$ & ANU-6022 & Organic matter & - & $3630 \pm 100$ & $4250-3600$ \\
\hline $236-246$ & ANU-6023 & Organic matter & - & $6370 \pm 160$ & $7600-6900$ \\
\hline $321-326$ & ANU-6024 & Organic matter & - & $7540 \pm 240$ & $9050-7850$ \\
\hline $396-406$ & ANU-6025 & Organic matter & - & $9710 \pm 200$ & $11850-10500$ \\
\hline $491-503$ & ANU-6026 & Organic matter & - & $11590 \pm 260$ & $14000-12950$ \\
\hline \multicolumn{6}{|l|}{ Core QH2000 } \\
\hline $50-51$ & Tka-12179 & Organic matter & -25.8 & $2700 \pm 100$ & $1820-1350$ \\
\hline $150-151$ & Tka-12180 & Organic matter & -25.8 & $4240 \pm 170$ & $3850-2950$ \\
\hline $150-151$ & Tka-12181 & Organic matter & -25.7 & $4010 \pm 100$ & $3380-2870$ \\
\hline $150-151$ & Tka-12182 & Organic matter & -25.3 & $4000 \pm 90$ & $3360-2880$ \\
\hline $230-231$ & Tka-12183 & Organic matter & -26.7 & $5060 \pm 90$ & $4850-4200$ \\
\hline $355-357$ & Tka-12184 & Organic matter & -22.3 & $6760 \pm 180$ & $7000-6100$ \\
\hline $475-477$ & Tka-12193 & Organic matter & -22.3 & $9660 \pm 140$ & $10200-9300$ \\
\hline $545-547$ & Tka-12185 & Organic matter & -23.2 & $14680 \pm 180$ & $16850-15550$ \\
\hline $675-677$ & Tka-12186 & Organic matter & -22.8 & $14820 \pm 180$ & $17050-15750$ \\
\hline $745-747$ & Tka-12236 & Organic matter & -25.0 & $15610 \pm 90$ & $18000-17050$ \\
\hline
\end{tabular}


Table 2

Sedimentation rates (mm/a) in Lake Qinghai during the last 200 years

\begin{tabular}{lllll}
\hline Site & ${ }^{210} \mathrm{~Pb}$ & ${ }^{137} \mathrm{Cs}$ & ${ }^{14} \mathrm{C}$ & Data sources \\
\hline QH85-14A & 0.51 & - & 0.32 & Huang and Sun (1989) \\
QH85-14C & 0.85 & - & - & Huang and Sun (1989) \\
QH85-16A & 0.42 & - & 0.44 & Huang and Sun (1989) \\
QH2000 & 1.30 & - & 0.32 & Shen et al. (2001) \\
QING 6 & 1.00 & 0.40 & 0.50 & Henderson (2004) \\
QING 10 & 1.30 & 1.50 & 0.15 & Henderson (2004) \\
QHE2/01 & 1.40 & 1.50 & 0.42 & Henderson (2004) \\
QH0407-C-2 & 1.00 & - & - & Xu et al. (2006a) \\
\hline
\end{tabular}

eastern sub-basin, consistent with greater shoreline erosion due to wave activity driven by the prevailing westerly winds.

\subsubsection{Climate and environment changes}

Detailed records from three sediment cores in the southern and southeastern part of the lake (Fig. 1B) cover the Lateglacial and Holocene. Pollen analyses and total organic carbon (TOC), total nitrogen (TN), grain size, and carbonate measurements were conducted on Cores QH8514 (Du et al., 1989; Kelts et al., 1989; Kong et al., 1990; Huang and Meng, 1991) and QH2000 (Liu et al., 2002, 2003a-c; Shen et al., 2005) to provide complementary information on productivity, sedimentation, and climate change. Core QH1, 350-cm long, was taken just $5 \mathrm{~m}$ south to Core QH85-16A (Fig. 1B) by the Lanzhou Institute of Geology, CAS. This core can be regarded as a replica of the upper part of Core QH85-16A. Laboratory analyses, including grain size, organic carbon, trace elements, and carbon isotopes, were conducted on this core, covering the last 8500 years (Guo et al., 2002a; Shi et al., 2003).

Proxy records correlate well between Cores QH85-14 and QH2000 (Fig. 3). TOC, TN contents and tree pollen percentages exhibit parallel changes among the cores. Five distinct stages of regional climate changes can be defined (Fig. 3), based on the various proxies. Minor increases in TOC, TN, and carbonate contents after ca 17000 cal yr BP indicate the termination of LGM. But the lake level was still low, and most of the OM was derived from the treeless catchment as indicated by less negative $\delta^{13} \mathrm{C}$ compared to earlier times. A decrease in tree pollen percentages between 12500 and 11500 cal yr BP may correlate with the Younger Dryas stadial ( $\mathrm{Yu}$ and Kelts, 2002), although chronologies are uncertain. Steady warming began at 11000 cal yr BP, along with higher primary productivity as marked by significant increases in TOC, TN, and carbonate content. This trend was frequently punctuated by a number of centennial-scale cooling, possibly including the "8.2-ka event", implying unstable climate conditions during the mid-Holocene climate optimum (Chen et al., 2001; Wunnemann et al., 2003). A significant shift in climate conditions occurred at $\sim 4000$ cal yr BP. The $\delta^{13} \mathrm{C}$ values continued to become more negative, possibly related to an increasing input of terrigenous $\mathrm{OM}$ as lake level continuously lowered. However, pollen records indicate that the $\mathrm{C}_{3} / \mathrm{C}_{4}$ ratio of the vegetation did not change significantly during the Holocene (Shen et al., 2005).

\subsubsection{Pollen record and vegetation history}

High-resolution pollen analyses were conducted on Cores QH85-14C (Du et al., 1989) and QH2000 (Shen et al., 2005). Preservation of pollen grains in sediments below $707 \mathrm{~cm}$ in Core QH2000 is very poor $(<100$ grains per slide), which makes it difficult to infer the composition of local vegetation. Nonetheless, the presence of Ephedra, Nitraria, and Chenopodiaceae below $707 \mathrm{~cm}$ appears to indicate a treeless alpine desert landscape during the LGM. Occurrences of Betula pollen could be the result of redeposition of former interglacial sediments or related to long-distance transport (Herzschuh et al., 2006a).

A prominent feature of Postglacial vegetation changes on the Tibetan Plateau is the Betula expansion (in the source areas, not necessarily the Qinghai basin) around 11000 cal yr BP (Herzschuh et al., 2006a), which then was followed by increases in Pinus around $8000 \mathrm{calyr}$ BP, indicating the onset of mid-Holocene Thermal Maximum. This pattern has been confirmed by a number of palynological studies in the neighboring areas (e.g. Van Campo et al., 1996; Tang et al., 2000), so that these pollen horizons can be used as time markers for synchronizing paleoclimatic records. Higher percentages of Betula and coniferous tree pollen have been interpreted as the presence of mixed forests in the alpine landscape of the Qinghai basin during the mid-Holocene Thermal Maximum (e.g. Tang, 2002). However, the distribution of modern vegetation on the Tibetan Plateau is governed by climate gradients - montane forests occur to the southeast and alpine steppe-desert to the western interior ( $\mathrm{Yu}$ et al., 2001). No broad-leaved trees grow in the Lake Qinghai area today. Based on regional distributions of modern vegetation, the colonization of broad-leaved trees in this area during the middle Holocene would require more than a ca $1000 \mathrm{~m}$ upward shift of timberline and a climate at least $5{ }^{\circ} \mathrm{C}$ warmer than present. However, quantitative climate reconstructions from fossil pollen in the Qilian Mountains indicate that the mid-Holocene Thermal Maximum in the NE Tibetan Plateau was only $1-2{ }^{\circ} \mathrm{C}$ warmer than today (Herzschuh et al., 2006a). Therefore, we believe that the broad-leaved tree pollen are exotic and represent long-distance transport from their source areas when the early summer monsoon winds are strong. If so, the application of transfer functions to climate reconstructions from pollen records in this area would be complicated.

\subsubsection{Ostracode carbonate trace elements and lake-water chemistry}

In many lake environments, climate plays a major role in lake water chemistry by changing the precipitation/ evaporation balance and thus the salinity of lake waters (Williams, 1966). As in marine carbonates, the $\mathrm{Mg} / \mathrm{Ca}$ and $\mathrm{Sr} / \mathrm{Ca}$ ratios in lacustrine carbonates change as a function of temperature and salinity, such that the $\mathrm{Mg} / \mathrm{Ca}$ ratio is a 
reflection of both water temperature and salinity, and the $\mathrm{Sr} / \mathrm{Ca}$ ratio is mainly a function of salinity (Chivas et al., 1986). In lake carbonates, these changes in trace-element chemistry can be recorded in ostracode shells, where the trace-element ratios are usually proportional to those in the ambient waters.

Several attempts to reconstruct salinity from trace elements in ostracode shells using the methods of Chivas et al. (1986) have been made for Lake Qinghai. These studies, including Zhang et al. (1989a, 1994) and Zhang et al. (2004), used partitioning coefficients determined by various calibration methods. However, several problems exist in using either $\mathrm{Mg} / \mathrm{Ca}$ or $\mathrm{Sr} / \mathrm{Ca}$ ratios to reconstruct water temperature or salinity in Lake Qinghai. First, because of the high $\mathrm{Mg}$ content of Lake Qinghai waters (Table 3), the primary precipitated carbonate is aragonite (Liu et al., 2003a). Although ostracode shells are made of low-Mg calcite, they can show evidence of aragonite

Table 3

Composition and changes of water chemistry in Lake Qinghai (after CASLZ and RCREWC-CAS, 1994; Chen et al., 1990)

\begin{tabular}{lccccc}
\hline Year & 1872 & 1880 & 1962 & 1986 & 1991 \\
\hline $\mathrm{K}^{+}$ & 0.12 & 0.11 & 0.15 & 0.16 & 0.16 \\
$\mathrm{Na}^{+}$ & 3.28 & 3.71 & 3.26 & 3.75 & 3.93 \\
$\mathrm{Ca}^{2+}$ & 0.19 & 0.00 & 0.01 & 0.01 & 0.01 \\
$\mathrm{Mg}^{2+}$ & 0.31 & 0.73 & 0.82 & 0.79 & 0.79 \\
$\mathrm{Cl}^{-}$ & 1.91 & 5.40 & 5.28 & 5.87 & 5.79 \\
$\mathrm{SO}_{4}^{2-}$ & 0.87 & 2.11 & 2.03 & 2.38 & 2.35 \\
$\mathrm{HCO}_{3}^{-}$ & - & - & 0.53 & 0.69 & 0.68 \\
$\mathrm{CO}_{3}^{2-}$ & - & 1.73 & 0.42 & 0.52 & 0.52 \\
Salinity & 10.97 & 13.34 & 12.49 & 14.15 & 14.23 \\
\hline
\end{tabular}

Note: Unit in $\mathrm{mg} / \mathrm{L}$. overgrowths and possible diagenetic alteration in Lake Qinghai (Henderson, 1999). Such alteration obviously limits the usefulness of $\mathrm{Mg} / \mathrm{Ca}$ ratios. Secondly, existing calibrations of the partitioning coefficient for $\mathrm{Sr} / \mathrm{Ca}$ in relation to salinity are for low-Mg calcite, either in lacustrine (Chivas et al., 1986) or marine environments. Such calibrations show a linear relationship between the $\mathrm{Sr} / \mathrm{Ca}$ partitioning coefficient and salinity. No accepted calibration function exists for $\mathrm{Sr} / \mathrm{Ca}$ in ostracode shells in the presence of aragonite, as it preferentially absorbs $\mathrm{Sr}$ from lake water during aragonite precipitation, thus complicating the linear $\mathrm{Sr} / \mathrm{Ca}$ relationships to salinity in the calcite shells of ostracodes (Engstrom and Nelson, 1991). Therefore, salinity reconstruction based on trace element geochemistry of biogenic carbonate is extremely problematic for Lake Qinghai.

\subsubsection{Carbonate stable isotopes and lake hydrological and thermal conditions}

Pioneering stable-isotope measurements on ostracode shells were conducted by Lister et al. (1991) on samples from Core QH85-14B (Fig. 4A). This was the longest lacustrine carbonate oxygen-isotope record from the Tibetan Plateau at that time, and provides valuable insights into the dynamics of the Asian monsoon during the Lateglacial and Holocene (Wei and Gasse, 1999). Similar changes were revealed subsequently by Zhang et al. (1989a) from Core QH85-16A (Fig. 4B) and recently by Liu et al. (2007) from QH2000 (Fig. 4C). High values of $\delta^{18} \mathrm{O}$ prior to $14500 \mathrm{cal}$ yr BP reveal cold and dry climate conditions. Fluctuating but decreasing $\delta^{18} \mathrm{O}$ values occurred after $14500 \mathrm{cal}$ yr BP, suggesting an unsteady strengthening of summer monsoon. The advance of monsoon front slowed

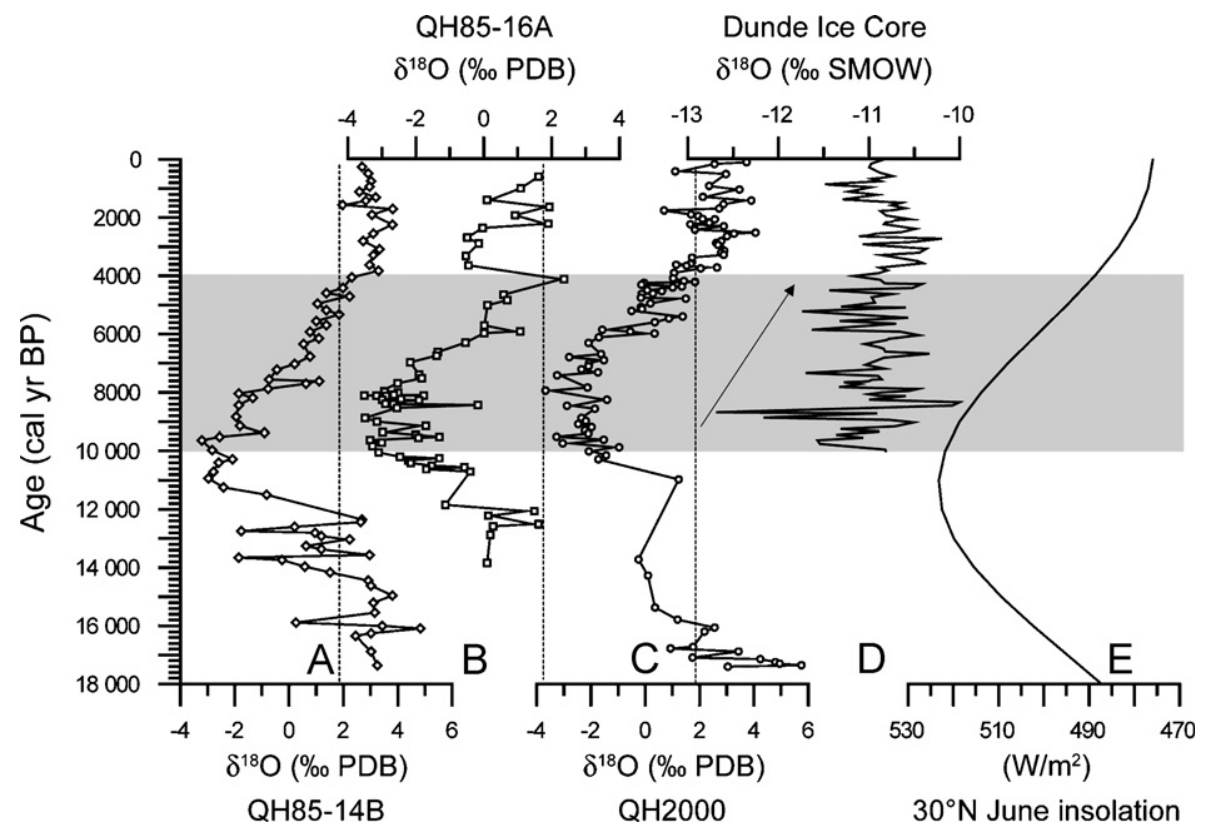

Fig. 4. Comparation of Lake Qinghai ostracode stable oxygen isotope records of Cores QH85-14B (Lister et al., 1991), QH85-16A (Zhang et al., 1989b), and QH2000 (Liu et al., 2007) with Dunde ice-core record (Thompson et al., 1989). Vertical lines indicate present-day $\delta^{18} \mathrm{O}$ value of lake water. Summer insolation data are from Berger and Loutre (1991). 
down at about $12000 \mathrm{cal}$ yr BP, possibly corresponding to the Younger Dryas stadial (Yu and Kelts, 2002). The summer monsoon culminated around $10000 \mathrm{cal} \mathrm{yr} \mathrm{BP.} \mathrm{A}$ nearly $6 \%$ enrichment of $\delta^{18} \mathrm{O}$ from about 11000 to 4000 cal yr BP suggests a gradual retreat of the summer monsoon. This trend also can be observed in the Dunde ice-core $\delta^{18} \mathrm{O}$ record (Fig. 4D). Parallel changes of the Dunde record with the Lake Qinghai records suggest that, unlike the Guliya ice core, continuous depletion of heavy oxygen isotopes in the Dunde ice core may be dominated by the "amount effect" associated with changes in monsoon intensity, modulated primarily by summer insolation to the middle latitudes (Fig. 4E). However, interpreting stable isotope records in terms of monsoon variations may be complicated due to spring water discharge to the lake, evidence of which is shown by the local presence of tufa (Zhang and Zhang, 1994).

Zhang and Zhang (1994) also reconstructed water temperature changes during the Holocene by assuming a temperature dependence of $\delta^{18} \mathrm{O}$ fractionation between ostracode shells and ambient waters. However, in a thermally stratified lake with a relatively constant hypolimnion temperature (ca $6{ }^{\circ} \mathrm{C}$ ) like Lake Qinghai, ostracode $\delta^{18} \mathrm{O}_{\mathrm{o}}$ is largely independent of temperature. Lake water $\delta^{18} \mathrm{O}_{\mathrm{w}}$ relates to the balance between the intensity of precipitation associated with the Asian Monsoon and evaporative effects in the closed basin (Wei and Gasse, 1999; Johnson and Ingram, 2004). Therefore, episodic depletions of $\delta^{18} \mathrm{O}_{\mathrm{o}}$ during the Lateglacial, e.g. the Bølling and Allerød interstadials, are likely to be manifestations of monsoon variations, rather than a signature of glacial meltwater discharge (e.g. Lister et al., 1991).

Unlike ostracode shells, the oxygen isotopes of authigenic carbonates $\left(\delta^{18} \mathrm{O}_{\mathrm{c}}\right)$ is controlled by both the temperature and oxygen isotope composition of surface water $\left(\delta^{18} \mathrm{O}_{\mathrm{w}}\right)$. The $\delta^{18} \mathrm{O}_{\mathrm{c}}$ is systematically higher than $\delta^{18} \mathrm{O}_{\mathrm{o}}$ in Lake Qinghai, and it has a large variability because it is subject to temperature effects in addition to the dominating evaporative effects. Therefore, comparing $\delta^{18} \mathrm{O}_{\mathrm{c}}$ with $\delta^{18} \mathrm{O}_{\mathrm{o}}$ may provide a new approach to estimating the vertical thermal structure of the lake (Kelts and Talbot, 1990), if the vital effects of the ostracodes are known. An example comes from Core QING6, where a systematic offset between $\delta^{18} \mathrm{O}_{\mathrm{c}}$ and $\delta^{18} \mathrm{O}_{\mathrm{o}}$ can be observed (Henderson et al., 2003). Assuming no isotopic stratification of the water body, this difference should be a result of oxygen-isotope fractionation induced by a temperature gradient between surface and bottom waters. This observation confirms the presence of a stable thermocline during summer, as suggested by thermodynamic hydrologic models (Qin and Huang, 1998b).

\subsection{The QING-6, QING-10, QHN3/1, QH0407-C, and GAHAI-1 records}

Climate changes during the last 1500 years were revealed by $\delta^{18} \mathrm{O}$ and $\delta^{13} \mathrm{C}$ records of fine-grained carbonate in
Cores QINH-6 and GAHAI-1 (Fig. 1B). These records show parallel changes and both cores indicate that regional climate has experienced considerable variability, including three distinct phases related to the Medieval Warm Period (A.D. 800-1200), the Little Ice Age (A.D. 1200-1850), and the post-Industrialization warming (Henderson, 2004). Comparing the $\delta^{18} \mathrm{O}$ record from Core QH0407-C with instrumental data suggests that the isotopic composition of fine-grained carbonates, which are formed in the epilimnion of the lake, primarily reflects the isotopic composition of the near-surface waters, which in turn is controlled by evaporative concentration associated with summer air temperature (Xu et al., 2006b). Consistent with these results are trends in both lake water temperature and salinity estimated in alkenone-based reconstructions on Core QHN3/1(Liu et al., 2006). The coherent changes in air temperature and precipitation are primarily related to variations of the Asian Summer Monsoon system.

\subsection{Recent changes}

\subsubsection{Lake levels and shorelines}

Past lake-level changes can be inferred from elevated terraces and beach ridges, although these features may be affected by local tectonics. Lacustrine terraces and beach ridges along the southern coast of Lake Qinghai have been described by Yuan et al. (1990) and Wang and Shi (1992). For example, three terraces can be identified at Jiangxigou. The first one above the Erlangjian terrace is very broad (3-4 km), and mainly overlain by fine sand. Its altitude is about $10 \mathrm{~m}$ above present lake level. Radiocarbon ages on organic clay indicate that this terrace was formed between 2000 and $1000{ }^{14} \mathrm{Cyr} \mathrm{BP}$. Below this terrace, six beach ridges situated at $1.5,2.0,3.0,3.5,5.7$, and $8.7 \mathrm{~m}$, respectively, were found (Yuan et al., 1990; Wang and Shi, 1992), indicating stillstands of the lake level superimposed upon a long-term lowering trend induced by either climate or tectonic uplift or both. None of the beach ridges are covered by loess, implying a young age. According to Kozloff's (1909) map, a 7-m-high beach ridge now separating Lake Erhai from Lake Qinghai must have developed sometime after 1909. In Daotang valley, the highest beach ridge, dated to $1230 \pm 60{ }^{14} \mathrm{C}$ yr BP (Wang and Shi, 1992), can be correlated to the first terrace at Jiangxigou.

The level of Lake Qinghai is very dynamic. The first lakelevel measurements were carried out by O.N. Potanen during 1884-1886, and then by B.A. Obruchev and W. Filchner (cf. Chen et al., 1990). According to their results, the lake level was ca $3205 \mathrm{~m}$ asl in the late $1880 \mathrm{~s}$ compared to 3193 now - it has been lowered by about $12 \mathrm{~m}$ during the last century or so. Regular meteorological and hydrological observations started in 1950. Instrumental data show that the lake level has continued to fall since 1958 (Fig. 5A). This is mainly caused by the 20th century warming in the area (Fig. 5B), which led to a negative precipitationevaporation balance (Fig. 5C) and reduced river runoff 


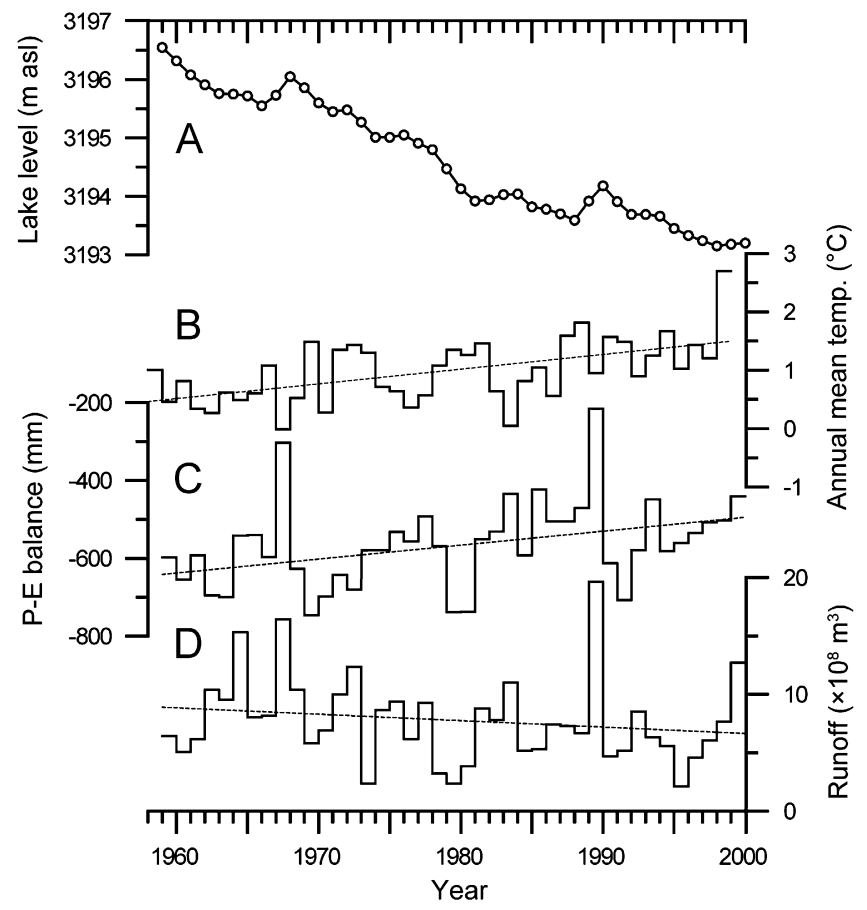

Fig. 5. Changes in lake level (A), annual mean temperature (B), precipitation-evaporation balance (C), and the Buha River runoff (D) since 1958. Dashed lines indicate the trend defined using a linear regression method.

(Fig. 5D). Agricultural and industrial water consumptions only account for $8 \%$ of this change (Qu, 1994). Four GCM experiments unanimously suggest that the local warming trend would continue under a scenario of doubling $\mathrm{CO}_{2}$ (Qin and Huang, 1998a). A hydrological model forced by the GCMs' outputs predicts dramatic increases in both summer precipitation and river runoff (Qin and Huang, 1998b), but they are not enough to offset increased evaporation. Consequently, the historical trend of lakelevel fall is likely to continue.

Lowering of lake level also led to progressive retreat of the shoreline and thus changes in the coastal landscape. According to Kozloff's (1909) map, Haiyan Bay and Lake Erhai used to be part of Lake Qinghai. Now the former has been isolated and the latter resembles a lagoon (Fig. 1B). In 1956, Bird Island was about $3800 \mathrm{~m}$ from the shore, and in 1972, only $2600 \mathrm{~m}$ (Guo, 1997). In a 1975 satellite image, this island was still separated from the mainland, but it was connected to the mainland by 1979 (Guo, 1997). Human activities, along with climate change, have also played an important role in modifying the coastal landscape. The Buha Delta prograded at a rate of $2 \mathrm{~km} / \mathrm{a}$ during the period from 1956 to 1968 (the so-called "Great Leap Campaign"), primarily caused by catchment erosion associated with extensive land reclamation (Zhang, 2003). Lobes of this delta have also changed greatly during the last half century: the active lobe was located $6.2 \mathrm{~km}$ north of Bird Island before the 1950s (Guo, 1997), but now is $4 \mathrm{~km}$ southwest of the island. The morphology of the northern shore also experienced substantial changes over the last 25 years. The shoreline there advanced at a rate of $130 \mathrm{~m} / \mathrm{a}$ due to increased catchment erosion (Zhang, 2003).

\subsubsection{Water chemistry}

No regular measurements of water chemistry have been made for Lake Qinghai. The earliest measurements were carried out by K. Schmidt in 1872 (cf. Chen et al., 1990). In 1962 and 1986, the Lanzhou Institute of Geology, CAS, and the Institute for Saltwater Lake Studies, CAS, performed routine measurements (CAS-LZ and RCREWC-CAS, 1994). The results indicate that the lake water is dominated by sodium and chloride. Sulfate and magnesium are also high. The chemical composition of the lake water did not change much during the last century (Table 3). The major biogeochemical processes in the lake is $\mathrm{CaCO}_{3}$ precipitation and biological reduction of sulfate to sulfide (Yan et al., 2002), which governs the concentration of magnesium and heavy metals in the lake water, respectively.

\section{Discussion and comparison with surrounding areas}

\subsection{Late Cenozoic changes}

Loess-soil sequences and the underlying Hipparion red clay formation contain abundant information on past climate changes in the western interior of China. For example, the Xifeng section in the western Loess Plateau (Liu et al., 2001), containing a red clay sequence overlain by a loess-soil complex, reveals a detailed history of the Asian monsoon system during the Late Cenozoic. Multiple stratigraphic analyses reveal that the eolian red clay started to accumulate at $\sim 8 \mathrm{Ma}$, evidently indicating the inception of the modern East Asian winter monsoon. This inception is most likely associated with the thermodynamic forcing of the rising Tibetan Plateau. Subsequent strengthening of the East Asian winter monsoon and the corresponding weakening of the summer monsoon appears to be a manifestation of global cooling after $3.6 \mathrm{Ma}$, especially when ice sheets expanded in the Northern Hemisphere at about 2.7 Ma (Maslin et al., 1998; An et al., 2001 Haug et al., 2005). Magnetic susceptibility records of the Xifeng section reveal low amplitude fluctuations of the Asian monsoon system with a $41-\mathrm{ka}$ frequency prior to $\sim 0.8 \mathrm{Ma}$ (Fig. 6A), which were then replaced by large-amplitude fluctuations with a 100-ka frequency, correlative with the deep-sea oxygen isotope record (Shackleton et al., 1995). The in-phase changes in the climate of inland China with global ice volume (Fig. 6B) imply a common force thought to be the variations in the orbital parameters of the earth.

Like the Loess Plateau, climate conditions on the Tibetan Plateau are influenced by the Asian monsoon system, which brings vapor to the interior of the northwestern China and feeds the lakes there. Like marine records (Prell and Kutzbach, 1992; Rea et al., 1998), continuous lacustrine records, can provide information, potentially complementary, about long-term changes in the 

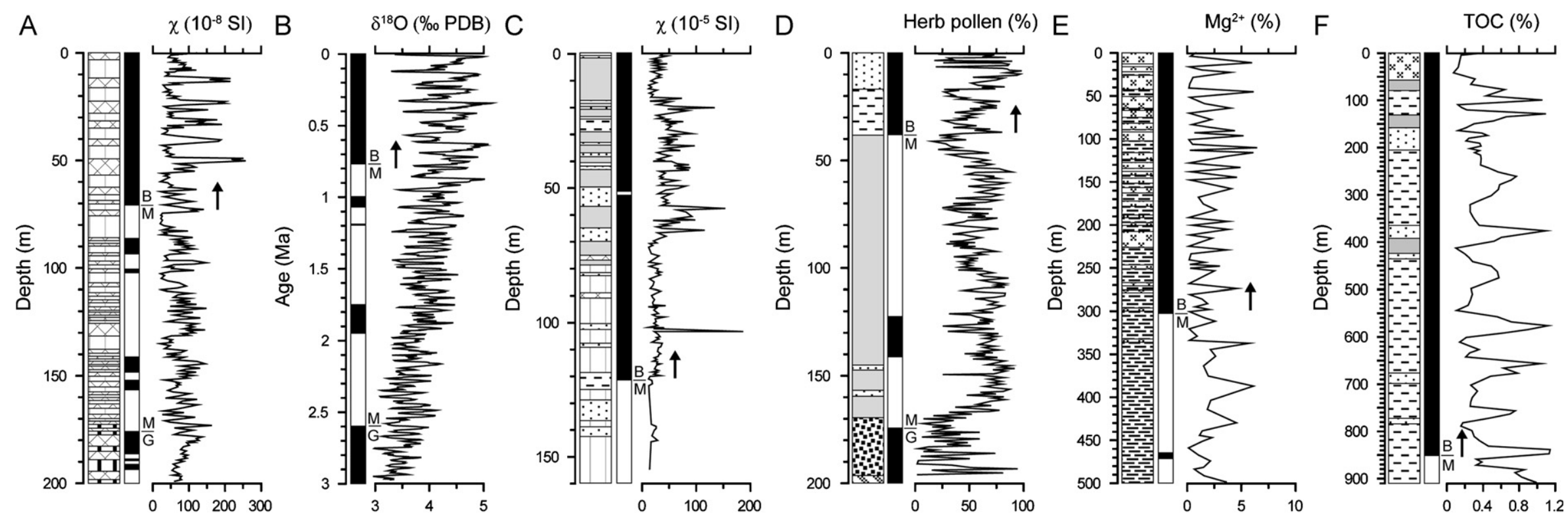

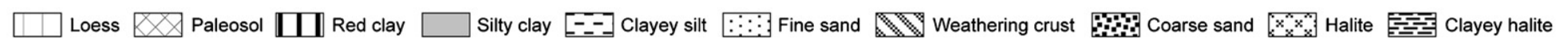

Fig. 6. Comparison of Pleistocene lacustrine records from the Tibetan Plateau with loess-soil and marine records. Arrows indicate the mid-Pleistocene transition. (A) Xifeng site, W. Loess Plateau (Liu et al., 2001); (B) Equatorial Pacific (Shackleton et al., 1995); (C) Lake Qinghai Core QH86, NE Tibetan Plateau (Yuan et al., 1990); (D) Co Ngoin, N. Tibetan Plateau (Lü et al., 2001); (E) Qunteyi Playa Core ZK3208, Qaidam Basin (Han et al., 1991); (F) Qarhan Playa Core CK-6, Qaidam Basin (Huang and Chen, 1990). 
Asian monsoon. Magnetic-susceptibility record of Core QH86 (Yuan et al., 1990) suggests orbital-scale fluctuations of Quaternary climate in China's inland (Fig. 6C). Largeamplitude oscillations of lake level occurred after $\sim 0.8 \mathrm{Ma}$, as indicated by repeated occurrences of silty clay above the $\mathrm{B} / \mathrm{M}$ polarity boundary. High-resolution pollen analyses from the Lake Co Ngoin core (Lü et al., 2001) reveal dampened fluctuations of the inland vegetation (and presumably climate) prior to $\sim 0.8 \mathrm{Ma}$ (Fig. 6D), which was then replaced by longer-period, large-amplitude changes. Reciprocal changes of alpine steppe and coniferous forests at a landscape scale after $\sim 0.8 \mathrm{Ma}$ are regulated by regional climate, rather than by inter-specific competition. A similar pattern of climate fluctuations is also registered in long drill cores from two playas in Qaidam Basin (Huang and Chen, 1990; Han et al., 1991). The halite-clay sequences (Fig. 6E and F), comparable to loesssoil sequences, reveal periodical changes in dry/wet conditions associated with substantial variations of the Asian monsoon after $\sim 0.8 \mathrm{Ma}$. Further evidence comes from a long drill core in Zoige Basin, where the organic carbon record suggests a similar pattern of inland climate fluctuations at orbital scales (Wang and Xue, 1997; Chen et al., 1999). Although mechanisms behind the shift from obliquity-dominated to eccentricity-dominated fluctuations, referred to as the "mid-Pleistocene transition," remain enigmatic, the existing long records do reveal an astronomical forcing of China's inland climate during the Quaternary.

In contrast to marine cores, lake sediments typically have higher sedimentation rates and thus can achieve finer time resolution. Lithological variations in lacustrine cores indicate different depositional environments, commonly having different sedimentation rates. Therefore, paleomagnetic stratigraphy alone is unable to provide detailed time constraints on long lacustrine records. In many of lakes on the Tibetan Plateau, carbonates dominate the authigenic minerals. Uranium-series disequilibrium dating on authigenic carbonates in the Balikun (Ma et al., 2004), Qarhan (Huang and Chen, 1990), and Qinghai (i.e. QH86; Shan et al., 1993) cores has proven promising accurate chronology for Pleistocene lacustrine records. Long and high-resolution record from Lake Qinghai with independent age controls will provide an opportunity not only to examine the dynamics of continental paleoclimate in both time and frequency domains, but also to evaluate the influence of reorganization of ocean circulation on the Asian monsoon system at millennial time scales.

\subsection{The Last Interglacial-Glacial cycle}

\subsubsection{Delayed response of the summer monsoon during the MIS6-MIS5e transition}

Periodical variations in Earth's orbital parameters have long been regarded as a pacemaker of past glacial-interglacial cycles. In some cases, however, discrepancies exist with orbital parameter, particularly for Termination II
(Winograd et al., 1988). The tuning of most marine records to fit orbital time scale, precludes the opportunity to address this problem. Therefore, high-resolution, welldated terrestrial records are important for understanding the mechanism and timing of deglaciation.

A speleothem record of $\delta^{18} \mathrm{O}$ from Dongge Cave (not shown; Yuan et al., 2004) indicates that the Asian summer monsoon slightly lagged behind insolation (Fig. 7A) during Termination II, but was almost concurrent with the rise of global sea level as revealed by benthic foraminifera $\delta^{18} \mathrm{O}$ record (Fig. 7B). A stacked marine record (Fig. 7C) indicates that full monsoon conditions did not occur until global sea level reached an interglacial position, which would enable the establishment of the Pacific warm pool, until about $125 \mathrm{ka}$ (Clemens and Prell, 2003). No cores from the last interglaciation yet exist for Lake Qinghai, but records from Zoige Basin (Fig. 7D), the Qarhan Playa (Fig. 7E), and the Loess Plateau (Fig. 7F) reveal a much more delayed response of the Asian summer monsoon to insolation. This difference will be scrutinized in the Lake Qinghai drill core.

Comparing these records with those from the western Tibetan Plateau and Tarim Basin may also reveal spatial variability of monsoon activity in this area during the Last Interglacial-Glacial cycle. The Guliya ice-core record (Fig. $7 \mathrm{G}$ ) indicates less negative $\delta^{18} \mathrm{O}$ values during interstadials, suggesting that the enrichment of oxygen isotopes in regional meteoric water was dominated by the "temperature effect" rather than the "amount effect" related to monsoon intensity that otherwise would deplete the heavy ${ }^{18} \mathrm{O}$. Further evidence comes from Lakes Tianshuihai (Fig. 7(H) and Balikun (Fig. 7I), which are located at the west side and north of the plateau, respectively. These two $\delta^{18} \mathrm{O}$ records resemble each other but are different than other records such as Zoige in the eastern part of the Plateau, indicating that the summer monsoon did not reach the western Tibetan Plateau and the Tarim Basin even during the Last Interglacial.

Loess records (Porter and An, 1995) reveal millennialscale variability of the Asian summer monsoon correlative with the North Atlantic Heinrich events during the Last Glaciation. And speleothem records (Wang et al., 2001) include even shorter events known as Dansgaard-Oeschger oscillations. However, existing lacustrine records from the Tibetan Plateau do not have the temporal resolution to identify these climate events. High-resolution lacustrine records from this area are needed not only to evaluate the rapidity of millennial-scale changes in summer monsoon, but also to examine the geographical extent of Heinrich and Dansgaard-Oeschger events outside the North Atlantic realm.

\subsubsection{The MIS3 period of anomalously high lake levels}

Lake sediments and landforms in the Qaidam basin (Chen et al., 1990) and other lakes on the Tibetan Plateau record a period of high lake levels attributed to MIS3 (Herzschuh, 2006b). In addition, the Guliya ice-core record 


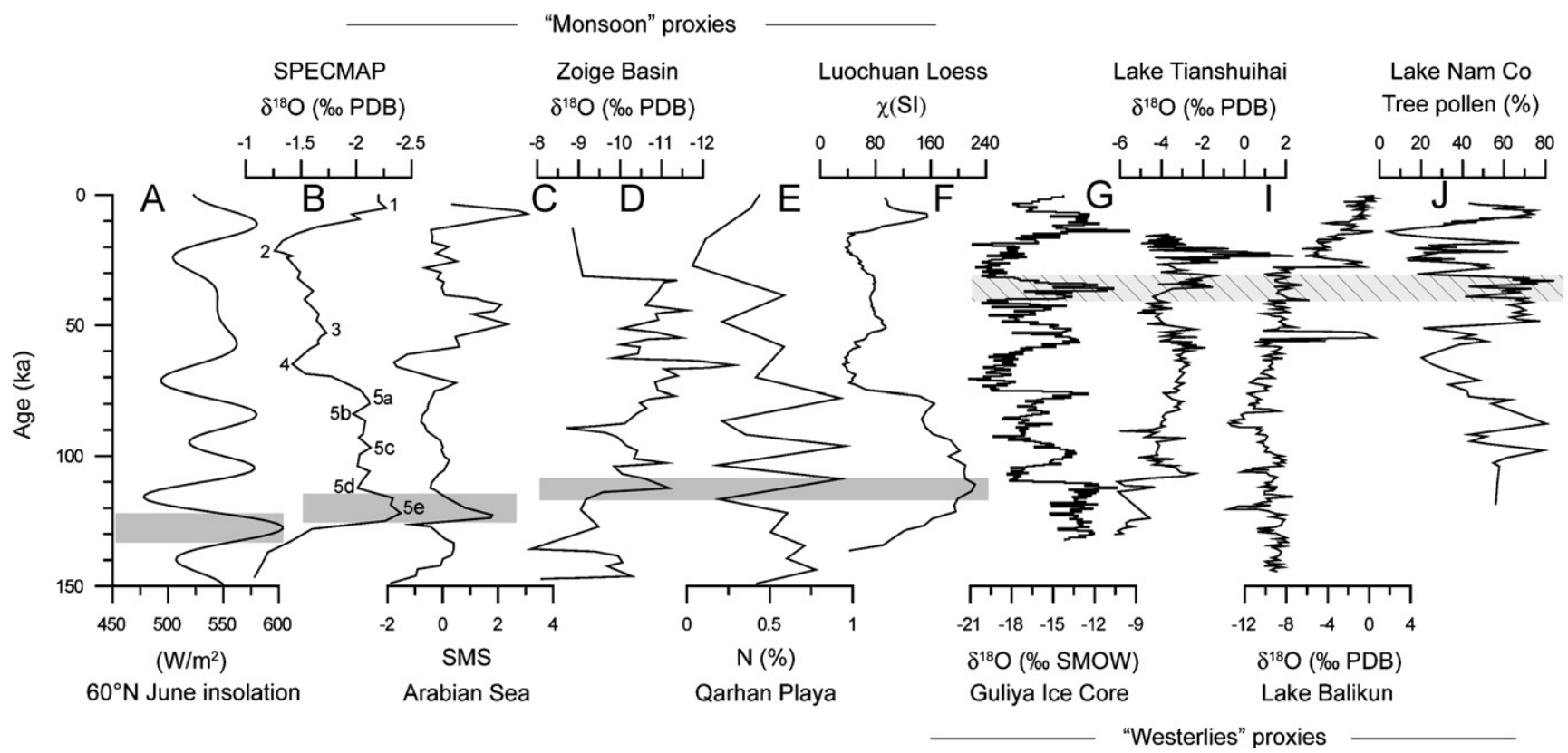

Fig. 7. Comparison of lacustrine records from the Tibetan Plateau with insolation and SPECMAP $\delta^{18} \mathrm{O}$ record during the last 150000 years. (A) Summer insolation (Berger and Loutre, 1991); (B) SPECMAP $\delta^{18}$ O record (Imbrie et al., 1993); (C) Arabian Sea summer monsoon stacked (SMS) record (Clemens and Prell, 2003); (D) Zoige Basin (Wu et al., 1997); (E) Qarhan Playa (Huang and Chen, 1990); (F) Luochuan section, the Loess Plateau (Xiao et al., 1999); (G) Guliya Ice Core (Thompson et al., 1997); (H) Lake Tianshuihai (Zhou and Zhu, 2001); (I) Lake Balikun (Ma et al., 2004); (J) Nam Co (Wu et al., 2004). Core chronologies are those estimated in the original studies. Arabic numerals denote Marine Isotope Stages. Shaded bands highlight the phase relationship of summer monsoon with insolation and global ice volume. The late MIS3 interval of extremely high lake levels is indicated by the hatched band.

Table 4

Reconstructed precipitation on the Lake Qinghai watershed using an energy-balance model

\begin{tabular}{lllllll}
\hline Age (cal yr BP) & $\begin{array}{l}\text { Lake level } \\
\text { anomaly }(\mathrm{m})\end{array}$ & $\begin{array}{l}\text { Lake surface area } \\
\left(\mathrm{km}^{2}\right)\end{array}$ & $\begin{array}{l}\text { Evaporation } \\
(\mathrm{mm})\end{array}$ & $\begin{array}{l}\text { Precipitation } \\
(\mathrm{mm})\end{array}$ & $\begin{array}{l}\text { River runoff } \\
\left(\times 10^{8} \mathrm{~m}^{3}\right)\end{array}$ \\
\hline $40000-30000$ & +104 & 8100 & 1015.0 & $645 \pm 5$ & - & Data sources \\
$7500-5000$ & +45 & 6406 & - & $595 \pm 15$ & - & Jia et al. (2000) \\
$7000-6000$ & +45 & 6225 & 1096.7 & 528.9 & 35.35 & Qin $(1994)$ \\
$7200-6000$ & +45 & 6225 & 1079.4 & 526.6 & 34.41 & Qin $(1997)$ \\
Modern & 0 & 4448 & 954.5 & 407.2 & 20.56 & Qin $(1997)$ \\
\hline
\end{tabular}

(Fig. 7G) reveals an anomalous warming on the Tibetan Plateau at the end of MIS3 (Thompson et al., 1997). High percentages of tree pollen in the Lake Nam Co core also suggest a warm and wet phase between 40 and $30 \mathrm{ka}$ (Fig. $7 \mathrm{~J}$ ). This pattern is considerably different from global ice volume indicated by the SPECMAP benthic oxygen isotope record (Fig. 7B).

Further evidence of high lake levels on the Tibetan Plateau comes from a large number of elevated terraces in several basins located at altitudes ranging from 10 to $280 \mathrm{~m}$ above present-day lake levels (Lehmkuhl and Haselein, 2000; Shi et al., 2002; Yang et al., 2004). For example, four terraces can be identified on the southern shore of Lake Qinghai. The highest one, situated at $\sim 120 \mathrm{~m}$ above present lake level, was interpreted as having formed about 38000 cal yr BP, and a second one at $\sim 45 \mathrm{~m}$ was dated to about 7500 cal yr BP (Chen et al., 1990; Yuan et al., 1990). Lake terraces are the product of stable lake levels, when precipitation is balanced by evaporation. Therefore, an energy-balance model, originally developed by Kutzbach (1980) for a hydrologically closed watershed, can be used to estimate past precipitation using estimated watershed evaporation (Qin, 1994, 1997; Jia et al., 2000). Evaporation is catchment-dependent and can be parameterized using vegetation cover and the insolation values during specific time intervals. The reconstructed annual precipitation and lake-surface evaporation suggest that MIS3 interval of high lake levels is $\sim 1.5$ times higher than that of present (Table 4). Higher lake-surface evaporation was presumably offset by increased river runoff to maintain stable lake levels.

The volume of ice during the LGM on the mountains in the Lake Qinghai basin has been estimated at $200 \pm 50 \mathrm{~km}^{3}$ (Wang and Shi, 1992). Conservatively assuming no change in lake surface area $\left(4400 \mathrm{~km}^{2}\right)$, melting of these mountain glaciers would have only raised lake level by $41 \pm 10 \mathrm{~m}$. 
Therefore, meltwater from mountain glaciers alone cannot account for the $\sim 104-\mathrm{m}$-high relative lake level, and tectonic deformation must be considered. On the Erlangjian terrace, a cross-bedded gravel unit that presumably was deposited near the shore suggests that the relative lake level has only dropped $\sim 6 \mathrm{~m}$ since the LGM (Yuan et al., 1990).

Some pollen records, mostly from relatively large lakes, have high amounts (ca $30 \%$ of the total) of tree pollen at $30-40 \mathrm{ka}$, which has been interpreted as indicating relatively warm, moist climate, perhaps comparable to conditions in the early Holocene (e.g. Herzschuh et al., 2006a). The tree pollen in such sequences is dominated by Abies and Picea, which are derived locally (Herzschuh et al., 2006a), as confirmed by the presence of their macrofossils (Wang and Shi, 1992). Tree pollen that might be interpreted as indicating mixed forests, Pinus and Betula pollen, only account for about $5 \%$, and thus probably represent long-distant transport rather than local mixed forests. Mixed forests of Pinus and Betula do not occur on the Tibetan Plateau today (Yu et al., 2001), although trap studies reveal the presence of their pollen (Cour et al., 1999). Thus, available pollen evidence from the Lake Qinghai area do not support conditions significantly wetter than the early Holocene during MIS3.

The altitude of the highest terraces around Lake Qinghai exhibit spatial variability, implying complex tectonic activities (Chen and Lin, 1993). For example, at Jiangxigou, the highest terrace is situated at $\sim 104 \mathrm{~m}$. A radiocarbon date of $12100 \pm 265 \mathrm{yr} \mathrm{BP}$ on charcoal (Wang and Shi, 1992) suggests that this terrace was formed during the Bølling-Allerød interstadials, rather than during MIS3. This compares with the $120 \mathrm{~m}$ terrace, with an estimated age of 38000 cal yr BP, discussed earlier.

The mechanism responsible for the supposed MIS3 moist interval is open to debate. Because this period shows a perfect correlation with higher summer isolation at $30^{\circ} \mathrm{N}$ (Berger and Loutre, 1991), when the perihelion (i.e. precession-controlled insolation) minima occurred during summer, Shi et al. (2001) ascribed this event to the strengthening of the Asian monsoon driven by the precession cycle. However, most monsoon records do not show any strengthening between 40 and $30 \mathrm{ka}$ (Figs. 7C-F). Furthermore, the Indian monsoon tends to be more sensitive to the obliquity component of orbital forcing (Clemens and Prell, 2003), which governs latent heat transport from the southern subtropical Indian Ocean and thus controls the thermal contrast between the Asian landmass and the ocean. Yang et al. (2004) argued against the monsoon hypothesis, suggesting that a moist climate during MIS3 could be better explained by the strengthened westerlies. The Tianshuihai and Balikun records (Figs. 7H and I) may provide an opportunity to test this idea, because climate conditions there are dominantly controlled by the westerlies. Carbonate $\delta^{18} \mathrm{O}$ values in both cores progressively increase during the MIS 3, implying an aridification trend into the LGM.

\subsection{Lateglacial-Holocene changes}

A large number of lacustrine records cover the last 14500 years on the Tibetan Plateau. Carbonate $\delta^{18} \mathrm{O}$ records and their paleoclimatic implications have been thoroughly reviewed by Wei and Gasse (1999), and palynological work was recently summarized by Shen (2003). All of these records reveal an initial warming of regional climate after $\sim 14500$ cal yr BP, accompanied by penetration of the summer monsoon into the eastern part of the plateau (He et al., 2004). Warm and wet conditions probably facilitated human colonization in this area (Madsen et al., 2006). These trends were punctuated by a cold spell between 12500 and 11000 cal yr BP, probably corresponding to the Younger Dryas interval (Gasse and Vancampo, 1994), although existing chronologies leave uncertainties about Younger Dryas correlatives. A gradual cooling of regional climate occurred after 10000 cal yr BP (Herzschuh et al., 2006c), along with a progressive retreat of the summer monsoon front (Hong et al., 2003). Regional climate turned distinctly cooler and drier about $5000 \mathrm{cal} \mathrm{yr} \mathrm{BP}$, as indicated by a sudden transition from temperate steppe to alpine steppe (Herzschuh et al., 2006c). The deteriorations of climate conditions are thought to be the major driving force in the termination of Neolithic cultures in this area (Rhode et al., 2007). Superimposed upon this trend were centennial-scale fluctuations with small amplitude, presumably induced by variation in solar activity (Ji et al., 2005).

Because Lake Qinghai is situated near the limit of monsoonal precipitation, variations of the Asian summer monsoon may have left its fingerprint on the lake's sediments. Therefore, the Lake Qinghai record is important for examining the spatial variability of the Asian Summer Monsoon, along with other records from neighboring areas. The $\delta^{18} \mathrm{O}$ records of lakes in the western part of the Tibetan Plateau, e.g. Sumxi-Longmu Co (Fontes et al., 1993), and Bangong Co (Fontes et al., 1996), exhibit a different pattern than the Lake Qinghai record (Lister et al., 1991), implying that the Indian Summer Monsoon did not reach the western Tibetan Plateau during the Holocene. However, several lakes, including Lakes Manas (Rhodes et al., 1996) and Issyk-Kul (Ricketts et al., 2001) show patterns of increased moisture during the midHolocene Thermal Maximum, similar to the record at Qinghai (Lister et al., 1991). It is not clear whether the moist intervals at these lakes were due to monsoonal precipitation or other causes.

\section{Summary and conclusions}

1. Comparisons of long Pleistocene lacustrine and loesssoil records with the marine oxygen isotope record show in-phase changes of China's inland climate with global ice volume, presumably driven by periodical variations in the Earth's orbital geometry. Once the plateau reached its threshold altitude for modifying the prevail- 
ing wind regime, subsequent uplift had little influence on regional climate. No independent evidence supports a tectonic forcing of these glacial-interglacial cycles.

2. Lacustrine carbonate $\delta^{18} \mathrm{O}$ and pollen records from the Tibetan Plateau suggest a delayed response of the Asian monsoon system to orbital forcing during Termination I and II. Strengthening of the summer monsoon lagged behind sea level by several thousand years, implying the importance of sea surface conditions in the development of monsoon circulation. Marine records from neighboring areas exhibit nothing anomalous in the Indian Summer Monsoon during MIS3, compared to the SPECMAP record. In addition, a lacustrine $\delta^{18} \mathrm{O}$ record from the northern margin of Tarim Basin reveals a steady drying trend through late MIS3 into the LGM. Therefore, the extremely high lake levels and inferred warming postulated for the Tibetan Plateau remains an enigma.

3. A wealth of evidence from Lake Qinghai reveals a teleconnection of China's inland climate with that of high northern latitudes during the Lateglacial and Holocene. Initial warming began at about $14500 \mathrm{calyr}$ BP, marking strengthening of the Asian summer monsoon after the last glaciation. The Lateglacial climate was remarkably unstable, as indicated by several cold reversals presumably related to glacial boundary conditions before the disappearance of Northern Hemisphere ice sheets. Steady warming started at $11000 \mathrm{calyr}$ BP and terminated about $4000 \mathrm{calyr}$ BP. High summer insolation resulted in a strong Asian summer monsoon between 11000 and 7000 cal yr BP. A striking feature of the Lake Qinghai record is the variability of the mid-Holocene Thermal Maximum at centennial time scales, probably caused by localized feedbacks, because similar changes have not been reported elsewhere.

4. Geological evidence suggests that the continued lowering of water level in Lake Qinghai within the context of global warming during the last half century is part of a long-term trajectory of aridification. Human impacts are minor in the Lake Qinghai basin. Modern studies of the limnological processes in the lake are badly needed. Such studies are important not only for interpreting paleolimnological data, but also for calibrating model parameters.

\section{Acknowledgments}

S.-Y. Yu thanks the State Key Laboratory of Loess and Quaternary Geology at the Institute of Earth Environment, Chinese Academy of Sciences for supporting his trip to China, and the National Science Foundation of China (NSFC) for supporting his short-term work in Nanjing University with Prof. Cheng Zhu (Grant No. 40410404026). We thank Dr. C.-M. Ma for the assistance while collecting the Chinese-language literature about Lake
Qinghai. Ulrike Herzschuh provided a thorough and helpful review of the manuscript. This work was partially supported by National Science Foundation grant EAR-0602412 to Colman.

\section{Note added in proof}

After completion of this paper, we became aware of an unpublished Ph.D. dissertation (Yu, J.-Q., 2005, Lake Qinghai, China: A multi-proxy investigation on sediment cores for the reconstructions of paleoclimate and paleoenvironment since the Marine Isotope Stage 3, University of Technology, Darmstadt, Germany, 119pp.) that deals with many aspects of the paleoclimate record of Lake Qinghai, only some of which has been published (see references). In particular, the dissertation describes a 1987 drilling effort that recovered a $26 \mathrm{~m}$ core (Q87) from the eastern basin of the lake. Limited data from this core suggest that it extends through sediments of MIS 3 age and that the lake was than present throughout that time.

\section{References}

An, Z.S., 2000. The history and variability of the East Asian paleomonsoon climate. Quaternary Science Reviews 19, 171-187.

An, Z.S., Kutzbach, J.E., Prell, W.L., Porter, S.C., 2001. Evolution of Asian monsoons and phased uplift of the Himalayan Tibetan plateau since Late Miocene times. Nature 411, 62-66.

An, Z.S., Wang, P., Shen, J., Zhang, Y.X., Zhang, P.Z., Wang, S.M., Li, X.Q., Sun, Q.L., Song, Y.G., Ai, L., Zhang, Y.C., Jiang, S.R., Liu, X.Q., Wang, Y., 2006. Geophysical survey on the tectonic and sediment distribution of Qinghai Lake basin. Science in China Series D 49, 851-861.

Berger, A., Loutre, M.F., 1991. Insolation values for the climate of the last 10 million years. Quaternary Science Reviews 10, 297-317.

Bian, Q., Liu, J., Luo, X., Xiao, J., 2000. Geotectonic setting, formation and evolution of Qinghai Lake, Qinghai, China. Seismology and Geology 22, 20-26 (in Chinese, with English Abstract).

Cane, M.A., Molnar, P., 2001. Closing of the Indonesian seaway as a precursor to east African aridification around 3-4 million years ago. Nature 411, 157-162.

Chen, F.H., Liu, G.X., Bloemendal, J., Zhang, P.Z., 1999. An 800 ky proxy record of climate from lake sediments of the Zoige Basin, eastern Tibetan Plateau. Palaeogeography, Palaeoclimatology, Palaeoecology 151, 307-320.

Chen, F.H., Zhu, Y., Li, J.J., Shi, Q., Jin, L.Y., Wunemann, B., 2001. Abrupt Holocene changes of the Asian monsoon at millennial- and centennial-scales: evidence from lake sediment document in Minqin Basin, NW China. Chinese Science Bulletin 46, 1942-1947.

Chen, G.C., Peng, M., 1993. Types and distribution of vegetation in Qinghai Lake region. Acta Phytoecologica et Geobotanica Sinica 17, 71-81 (in Chinese, with English Abstract).

Chen, K.Z., Huang, D.F., Liang, D.G., 1964. Formation and evolution of Lake Qinghai. Acta Geographica Sinica 30, 214-230 (in Chinese, with English Abstract).

Chen, K.Z., Bowler, J.M., Kelts, K.R., 1990. Palaeoclimatic evolution within the Qinghai-Xizang (Tibet) Plateau in the last 40,000 years. Quaternary Sciences, 21-31 (in Chinese, with English Abstract).

Chen, Y.D., 1987a. Potamogetonaceae plants in Lake Qinghai. Journal of Aquatic Botany 11, 225-235 (in Chinese, with English Abstract).

Chen, Y.D., 1987b. Cyperacea plants in Lake Qinghai. Botanical Studies 7, 115-128 (in Chinese, with English Abstract). 
Chen, Z.E., Lin, Q.Y., 1993. Significance of neotectonic movement of lake extension and shrinkage in Qinghai-Tibet Plateau. Earthquake 1, 31-40 (in Chinese, with English Abstract).

Chinese Academy of Science Lanzhou (CAS-LZ), Research Center for Resource and Environment of Western China, Chinese Academy of Sciences (RCREWC-CAS ), 1994. Evolution of Recent Environment in Qinghai Lake and Its Prediction. China Science Press, Beijing.

Chivas, A.R., Dedeckker, P., Shelley, J.M.G., 1986. Magnesium content of non-marine ostracod shells - a new paleosalinometer and paleothermometer. Palaeogeography Palaeoclimatology Palaeoecology $54,43-61$.

Chung, S.L., Lo, C.H., Lee, T.Y., Zhang, Y.Q., Xie, Y.W., Li, X.H., Wang, K.L., Wang, P.L., 1998. Diachronous uplift of the Tibetan plateau starting $40 \mathrm{Myr}$ ago. Nature 394, 769-773.

Clemens, S.C., Prell, W.L., 2003. A 350,000 year summer-monsoon multiproxy stack from the Owen Ridge, Northern Arabian Sea. Marine Geology 201, 35-51.

Coleman, M., Hodges, K., 1995. Evidence for Tibetan Plateau uplift before $14 \mathrm{Myr}$ ago from a new minimum age for east-west extension. Nature 374, 49-52.

Colman, S.M., 1996. Continental drilling for Paleoclimatic records: recommendations from an international workshop: Bern, Switzerland. PAGES Workshop Report Series 96-4, 104pp.

Colman, S.M., Peck, J.A., Karabanov, E.B., Carter, S.J., Bradbury, J.P., King, J.W., Williams, D.F., 1995. Continental climate response to orbital forcing from biogenic silica records in Lake Baikal. Nature 378, 769-771.

Cour, P., Zheng, Z., Duzer, D., Calleja, M., Yao, Z., 1999. Vegetational and climatic significance of modern pollen rain in northwestern Tibet. Review of Palaeobotany and Palynology 104, 183-204.

Dettman, D.L., Fang, X.M., Garzione, C.N., Li, J.J., 2003. Uplift-driven climate change at $12 \mathrm{Ma}$ : a long ${ }^{18} \mathrm{O}$ record from the $\mathrm{NE}$ margin of the Tibetan Plateau. Earth and Planetary Science Letters 214, 267-277.

Du, N.Q., Kong, Z.C., Shan, F.S., 1989. A preliminary investigation on the vegetational and climatic changes since 11,000 years in Qinghai Lake - an analysis based on palynology in core QH85-14C. Acta Botanica Sinica 31, 803-814 (in Chinese, with English Abstract).

Engstrom, D.R., Nelson, S.R., 1991. Paleosalinity from trace-metals in fossil ostracodes compared with observational records at devils lake, North Dakota, USA. Palaeogeography Palaeoclimatology Palaeoecology $83,295-312$.

Fontes, J.C., Gasse, F., Melieres, F., Gibert, E., Liu, Q., 1993. Stable isotope and radiocarbon balances of two Tibetan lakes (Sumxi Co, Longmu Co) from 13,000 BP. Quaternary Science Reviews 12, 875-887.

Fontes, J.C., Gasse, F., Gibert, E., 1996. Holocene environmental changes in Lake Bangong Basin (western Tibet). Part 1: chronology and stable isotopes of carbonates of a Holocene lacustrine core. Palaeogeography, Palaeoclimatology, Palaeoecology 120, 25-47.

France-Lanord, C., Derry, L.A., 1997. Organic carbon burial forcing of the carbon cycle from Himalayan erosion. Nature 390, 65-67.

Gasse, F., Vancampo, E., 1994. Abrupt postglacial climate events in West Asia and North-Africa monsoon domains. Earth and Planetary Science Letters 126, 435-456.

Guo, W., 1997. Studies on changes in stage and evolution of ecological environment for the Qinghai Lake. Journal of Arid Land Resources and Environment 11, 75-80 (in Chinese, with English Abstract).

Guo, X.L., Wang, Q., Shi, J.A., Zhang, X.B., Zeng, F.G., Deng, J.H., 2002a. Characteristics of the total organic carbon and organic carbon isotope and grain size and paleoclimate significance in Qinghai Lake sediments. Marine Geology and Quaternary Geology 22, 99-103 (in Chinese, with English Abstract).

Guo, Z.T., Ruddiman, W.F., Hao, Q.Z., Wu, H.B., Qiao, Y.S., Zhu, R.X., Peng, S.Z., Wei, J.J., Yuan, B.Y., Liu, T.S., 2002b. Onset of Asian desertification by $22 \mathrm{Myr}$ ago inferred from loess deposits in China. Nature 416, 159-163.

Gupta, A.K., Singh, R.K., Joseph, S., Thomas, E., 2004. Indian Ocean high-productivity event $(10-8 \mathrm{Ma})$ : linked to global cooling or to the initiation of the Indian monsoons? Geology 32, 753-756.
Han, F.Q., Huang, Q., Wang, K.J., Wang, H.A., Yuan, L., 1991. Geochemical and palaeoclimatic changes of the Kunteyi Salt Lake in the Qaidam Basin. Salt Lakes Research, 1-6 (in Chinese, with English Abstract).

Harrison, T.M., Copeland, P., Kidd, W.S.F., Yin, A., 1992. Raising Tibet. Science $255,1663-1670$.

Haug, G.H., Tiedemann, R., 1998. Effect of the formation of the Isthmus of Panama on Atlantic Ocean thermohaline circulation. Nature 393, 673-676.

Haug, G.H., Ganopolski, A., Sigman, D.M., Rosell-Mele, A., Swann, G.E.A., Tiedemann, R., Jaccard, S.L., Bollmann, J., Maslin, M.A., Leng, M.J., Eglinton, G., 2005. North Pacific seasonality and the glaciation of North America 2.7 million years ago. Nature 433, 821-825.

Hay, W.W., Soeding, E., DeConto, R.M., Wold, C.N., 2002. The Late Cenozoic uplift - climate change paradox. International Journal of Earth Sciences 91, 746-774.

He, Y., Theakstone, W.H., Zhang, Z.L., Zhang, D.A., Yao, T.D., Chen, T., Shen, Y.P., Pang, H.X., 2004. Asynchronous Holocene climatic change across China. Quaternary Research 61, 52-63.

Henderson, A.C.G., 1999. Detecting climate change using a highresolution record from the recent lake sediments of Qinghai Hu, NE Tibetan Plateau, China. Master Thesis, University College London, UK.

Henderson, A.C.G., 2004. Late Holocene environmental change on the NE Tibetan Plateau: a palaeolimnological study of Lake Qinghai and Lake Gahai, China, based on stable isotopes. Ph.D. Thesis, University College London, UK.

Henderson, A.C.G., Holmes, J.A., Zhang, J.W., Leng, M.J., Carvalho, L.R., 2003. A carbon- and oxygen-isotope record of recent environmental change from Qinghai Lake, NE Tibetan Plateau. Chinese Science Bulletin 48, 1463-1468.

Herzschuh, U., 2006b. Palaeo-moisture evolution at the margins of the Asian monsoon during the last $50 \mathrm{ka}$. Quaternary Science Reviews 25, 163-178.

Herzschuh, U., Kürschner, H., Mischke, S., 2006a. Temperature variability and vertical vegetation belt shifts during the last $\sim 50,000 \mathrm{yr}$ in the Qilian Mountains (NE margin of the Tibetan Plateau, China). Quaternary Research 66, 133-146.

Herzschuh, U., Winter, K., Wünnemann, B., Li, S., 2006c. A general cooling trend on the central Tibetan Plateau throughout the Holocene recorded by the Lake Zigetang pollen spectra. Quaternary International 154-155, 113-121.

Hong, Y.T., Hong, B., Lin, Q.H., Zhu, Y.X., Shibata, Y., Hirota, M., Uchida, M., Leng, X.T., Jiang, H.B., Xu, H., Wang, H., Yi, L., 2003. Correlation between Indian Ocean summer monsoon and North Atlantic climate during the Holocene. Earth and Planetary Science Letters 211, 371-380.

Huang, Q., Chen, K.Z., 1990. Palaeoclimatic fluctuation fashion of Qarhan Salt Lake in Qaidam Basin in the past 730,000 years. Quaternary Sciences, 205-212 (in Chinese, with English Abstract).

Huang, Q., Meng, Z.Q., 1991. Study on features of evolution of palaeoclimate in arid and cold region (I) - organic geochemistry method for modelling palaeoclimate fluctuation. Oceanologia et Limnologia Sinica 22, 547-553 (in Chinese, with English Abstract).

Huang, Q., Sun, N.J., 1989. Preliminary study on depositing rate of Qinghai Lake and its evolution of paleoclimate. Chinese Science Bulletin 34, 1457-1462.

Imbrie, J., Berger, A., Boyle, E.A., Clemens, S.C., Duffy, A., Howard, W.R., Kukla, G., Kutzbach, J., Martinson, D.G., McIntyre, A., Mix, A.C., Molfino, B., Morley, J.J., Peterson, L.C., Pisias, N.G., Prell, W.L., Raymo, M.E., Shackleton, N.J., Toggweiler, J.R., 1993. On the structure and origin of major glaciation cycles 2: the 100,000-year cycle. Paleoceanography 8, 699-735.

Ji, J.F., Shen, J., Balsam, W., Chen, J., Liu, L.W., Liu, X.Q., 2005. Asian monsoon oscillations in the northeastern Qinghai-Tibet Plateau since the Late Glacial as interpreted from visible reflectance of Qinghai Lake sediments. Earth and Planetary Science Letters 233, 61-70. 
Jia, Y.L., Shi, Y.F., Fan, Y.Q., 2000. Water balance of paleolake Qinghai and its precipitation estimation at three high lake-level stages since $40 \mathrm{ka} \mathrm{BP}$. Journal of Lake Sciences 12, 211-218 (in Chinese, with English Abstract).

Johnson, K.R., Ingram, B.L., 2004. Spatial and temporal variability in the stable isotope systematics of modern precipitation in China: implications for paleoclimate reconstructions. Earth and Planetary Science Letters 220, 365-377.

Kelts, K.R., Talbot, M.R., 1990. Lacustrine carbonates as geochemical archives of environmental changes and biotic/abiotic interactions. In: Tilzer, M.M., Serruya, C. (Eds.), Large Lakes: Ecological Structure and Function. Science and Technology Publishers, Madison, WI, pp. 288-315.

Kelts, K.R., Chen, K.Z., Lister, G.S., Yu, J.Q., Gao, Z.H., Niessen, N., Bonani, G., 1989. Geological fingerprints of climate history: a cooperative study of Qinghai Lake, China. Eclogae Geologicae Helvetiae 82, 167-182.

Kong, Z.C., Du, N.Q., Shan, F.S., 1990. Vegetational and climatic changes in the last 11,000 years in Qinghai Lake - numerical analysis based on palynology in Core QH85-14C. Marine Geology and Quaternary Geology 10, 79-90 (in Chinese, with English Abstract).

Kozloff, P.K., 1909. The Mongolia-Sze-Chuan expedition of the Imperial Russian Geographical Society. The Geographical Journal 34, 384- 408.

Kutzbach, J.E., 1980. Estimates of past climate at paleolake Chad, North Africa, based on a hydrological and energy-balance model. Quaternary Research 14, 210-223.

Lanzhou Institute of Geology, Chinese Academy of Sciences (LZIGCAS), 1979. Qinghai Lake Monograph of the 1961 Expedition. China Science Press, Beijing.

Lehmkuhl, F., Haselein, F., 2000. Quaternary paleoenvironmental change on the Tibetan Plateau and adjacent areas (Western China and Western Mongolia). Quaternary International 65/66, 121-145.

Li, J.J., Fang, X.M., Pan, B.T., Zhao, Z.J., Song, Y.G., 2001. Late Cenozoic intensive uplift of Qinghai-Xizang Plateau and its impacts on environments in surrounding area. Quaternary Sciences 21, 381-391 (in Chinese, with English Abstract).

Lister, G.S., Kelts, K.R., Chen, K.Z., Yu, J.Q., Niessen, F., 1991. Lake Qinghai, China: closed-basin lake levels and the oxygen isotope record for ostracoda since the latest Pleistocene. Palaeogeography, Palaeoclimatology, Palaeoecology 84, 141-162.

Liu, X., Yin, Z.Y., 2002. Sensitivity of East Asian monsoon climate to the uplift of the Tibetan Plateau. Palaeogeography, Palaeoclimatology, Palaeoecology 183, 223-245.

Liu, X.M., An, Z.S., Rolph, T., Qiang, X.K., Hesse, P., Lu, H.Y., Zhou, J., Cai, Y.J., 2001. Magnetic properties of the Tertiary red clay from Gansu Province, China and its paleoclimatic significance. Science in China Series D 44, 635-651.

Liu, X.Q., Shen, J., Wang, S.M., Yang, X.D., Tong, G.B., Zhang, E.L., 2002. A 16-ka pollen record of Lake Qinghai and its implications for paleoclimate and paleoenvironment changes. Chinese Science Bulletin 47, 1351-1355 (in Chinese, with English Abstract).

Liu, X.Q., Shen, J., Wang, S.M., Zhang, E.L., Cai, Y.F., 2003a. A 16,000year paleoclimatic record derived from authegenic carbonate of lacustrine sediment in Qinghai Lake. Geological Journal of China Universities 9, 38-46 (in Chinese, with English Abstract).

Liu, X.Q., Wang, S.M., Shen, J., 2003b. The grain size of the Core QH2000 in Qinghai Lake and its implication for paleoclimate and paleoenvironment. Journal of Lake Sciences 15, 112-117 (in Chinese, with English Abstract).

Liu, X.Q., Wang, S.M., Shen, J., Zhang, E.L., 2003c. Changes in organic carbon isotope of Lake Qinghai sediments and its control factors since 16 ka. Progress in Natural Sciences 13, 169-173 (in Chinese, with English Abstract).

Liu, X.Q., Shen, J., Wang, S.M., Wang, Y.B., Liu, W.G., 2007. Southwest monsoon changes indicated by oxygen isotope of ostracode shells from sediments in Qinghai Lake since the Late Glacial. Chinese Science Bulletin 52, 539-544.
Liu, Z.H., Henderson, A.C.G., Huang, Y.S., 2006. Alkenone-based reconstruction of late-Holocene surface temperature and salinity changes in Lake Qinghai, China. Geophysical Research Letters 33, L09707.

Lü, H., Yang, X., Shen, C., Li, S., Zhu, L., Wang, L., Wang, S., Wu, N., Tong, G., 2001. A new pollen record of the last $2.8 \mathrm{Ma}$ from the Co Ngoin, Central Tibetan Plateau. Science in China Series D 44, 292-300.

Ma, Y.Z., Li, J.J., Fang, X.M., 1998. Pollen assemblage in 30.6-5.0 Ma redbeds of Linxia region and climate evolution. Chinese Science Bulletin 43, 301-304 (in Chinese, with English Abstract).

Ma, Z.B., Wang, Z.H., Liu, J.Q., Yuan, B.Y., Xiao, J.L., Zhang, G.P., 2004. U-series chronology of sediments associated with Late Quaternary fluctuations, Balikun Lake, northwestern China. Quaternary International 121, 89-98.

Madsen, D.B., Ma, H., Brantingham, P.J., Gao, X., Rhode, D., Zhang, H., Olsen, J.W., 2006. The late Upper Paleolithic occupation of the northern Tibetan Plateau margin. Journal of Archaeological Science 33, 1433-1444.

Maslin, M.A., Berger, A., Li, X.S., Loutre, M.F., 1998. The contribution of orbital forcing to the progressive intensification of Northern Hemisphere glaciation. Quaternary Science Reviews 17, 411-426.

Metivier, F., Gaudemer, Y., Tapponnier, P., Meyer, B., 1998. Northeastward growth of the Tibet plateau deduced from balanced reconstruction of two depositional areas: the Qaidam and Hexi Corridor basins, China. Tectonics 17, 823-842.

Molnar, P., England, P., Martinod, J., 1993. Mantle dynamics, uplift of the Tibetan Plateau, and the Indian monsoon. Reviews of Geophysics 31, 357-396.

Porter, S.C., An, Z.S., 1995. Correlation between climate events in the North Atlantic and China during last glaciation. Nature 375, 305-308.

Porter, S.C., Singhvi, A., An, Z.S., Lai, Z.P., 2001. Luminescence age and palaeoenvironmental implications of a late Pleistocene ground wedge on the northeastern Tibetan Plateau. Permafrost and Periglacial Processes 12, 203-210.

Prell, W.L., Kutzbach, J.E., 1992. Sensitivity of the Indian monsoon to forcing parameters and implications for its evolution. Nature 360, 647-652.

Qin, B.Q., 1994. Estimates water balance of paleolake Qinghai in stable wet and warm period of Holocene. Advances in Water Science 5, 26-30 (in Chinese, with English Abstract).

Qin, B.Q., 1997. Estimates of paleo-hydrological parameters and water balance of Qinghai Lake with energy-water balance model. Oceanologia et Limnologia Sinica 28, 611-616 (in Chinese, with English Abstract).

Qin, B.Q., Huang, Q., 1998a. Evaluation of the climatic change impacts on the inland lake - a case study of Lake Qinghai, China. Climatic Change 39, 695-714.

Qin, B.Q., Huang, Q., 1998b. The simulation of thermal properties of Qinghai Lake and the potential change in the future. Journal of Lake Sciences 10, 25-31 (in Chinese, with English Abstract).

Qu, Y.G., 1994. Water balance and forecasting of water level change in Qinghai Lake. Journal of Lake Sciences 6, 298-307 (in Chinese, with English Abstract).

Quade, J., Cerling, T.E., Bowman, J.R., 1989. Development of Asian monsoon revealed by marked ecological shift during the latest Miocene in northern Pakistan. Nature 342, 163-166.

Ramstein, G., Fluteau, F., Besse, J., Joussaume, S., 1997. Effect of orogeny, plate motion and land-sea distribution on Eurasian climate change over the past 30 million years. Nature 386, 788-795.

Raymo, M.E., Ruddiman, W.F., 1992. Tectonic forcing of Late Cenozoic climate. Nature 359, 117-122.

Rea, D.K., Snoeckx, H., Joseph, L.H., 1998. Late Cenozoic eolian deposition in the North Pacific: Asian drying, Tibetan uplift, and cooling of the northern hemisphere. Paleoceanography 13, 215-224.

Rhode, D., Zhang, H., Madsen, D.B., Gao, X., Brantingham, P.J., Ma, H., Olsen, J.W., 2007. Epipaleolithic/early Neolithic settlements at Qinghai Lake, western China. Journal of Archaeological Science 34, 600-612. 
Rhodes, T.E., Gasse, F., Lin, R.F., Fontes, J.C., Wei, K.Q., Bertrand, P., Gibert, E., Melieres, F., Tucholka, P., Wang, Z.X., Cheng, Z.Y., 1996. A late Pleistocene-Holocene lacustrine record from Lake Manas, Zunggar (northern Xinjiang, western China). Palaeogeography Palaeoclimatology Palaeoecology 120, 105-121.

Ricketts, R.D., Johnson, T.C., Brown, E.T., Rasmussen, K.A., Romanovsky, V.V., 2001. The Holocene paleolimnology of Lake Issyk-Kul, Kyrgyzstan: trace element and stable isotope composition of ostracodes. Palaeogeography Palaeoclimatology Palaeoecology 176, 207-227.

Ruddiman, W.F., Kutzbach, J.E., 1989. Forcing of Late Cenozoic Northern Hemisphere climate by plateau uplift in southern Asia and the American west. Journal of Geophysical Research 94, 18409-18427.

Ruddiman, W.F., Prell, W.L., Raymo, M.E., 1989. Late Cenozoic uplift in southern Asia and the American west: rationale for general circulation modeling experiments. Journal of Geophysical Research 94, 18379-18391.

Shackleton, N.J., Hall, M.A., Pate, D., 1995. Pliocene stable isotope stratigraphy of Site 846. In: Pisias, N.G., Janacek, L.A., PalmerJulson, A., Van Andel, T.H. (Eds.), Proceedings of the Ocean Drilling Program Scientific Results, pp. 337-355.

Shan, F.S., Du, N.Q., Kong, Z.C., 1993. Vegetational and environmental changes in the last $350 \mathrm{ka}$ in Erlangjian, Qinghai Lake. Journal of Lake Sciences 5, 9-17 (in Chinese, with English Abstract).

Shen, C.M., 2003. Millennial-scale variations and centennial-scale events in the Southwest Asian monsoon: Pollen evidence from Tibet. Ph.D. Thesis, Louisiana State University, USA.

Shen, J., Liu, X.Q., Wang, S.M., Matsumotob, R., 2005. Palaeoclimatic changes in the Qinghai Lake area during the last 18,000 years. Quaternary International 136, 131-140.

Shen, J., Zhang, E.L., Xia, W.L., 2001. Records from lake sediments of the Qinghai Lake to mirror climatic and environmental changes of the past about 1000 years. Quaternary Sciences 21, 508-513 (in Chinese, with English Abstract).

Shi, J.A., Guo, X.L., Wang, Q., Yan, N.Z., Wang, J.X., 2003. Geochemistry of REE in QH1 sediments of Qinghai Lake since late Holocene and its paleoclimatic significance. Journal of Lake Sciences 15, 28-34 (in Chinese, with English Abstract).

Shi, Y.F., Jia, Y.L., Yu, G., Yang, D.Y., Fan, Y.Q., Li, S.J., Wang, Y.F., 2002. Features, impacts and causes of the high temperature and large precipitation event in the Tibetan Plateau and its adjacent area during 40-30 ka BP. Journal of Lake Sciences 14, 1-11 (in Chinese, with English Abstract).

Shi, Y.F., Lu, M.X., Li, W.Z., 1958. Physical geography with emphasis on geomorphology around Lake Qinghai. Acta Geographica Sinica 24, 33-48 (in Chinese, with English Abstract).

Shi, Y.F., Yu, G., Liu, X.D., Li, B.Y., Yao, T.D., 2001. Reconstruction of the 30-40 ka BP enhanced Indian monsoon climate based on geological records from the Tibetan Plateau. Palaeogeography Palaeoclimatology Palaeoecology 169, 69-83.

Sun, D.P., Tang, Y., Xu, Z.Q., Han, Z.M., 1991. A preliminary investigation on chemical evolution of the Qinghai Lake water. Chinese Science Bulletin 36, 1172-1174 (in Chinese, with English Abstract)

Tang, L.Y., 2002. Temporal-spatial distribution of vegetation in the Qinghai-Xizang Plateau during the past $12 \mathrm{ka} \mathrm{BP}$. Acta Botanica Sinica 44, 872-877 (in Chinese, with English Abstract).

Tang, L.Y., Shen, C.M., Liu, K.B., Overpeck, J.T., 2000. Changes in South Asian monsoon: new high-resolution paleoclimatic records from Tibet, China. Chinese Science Bulletin 45, 87-91.

Thompson, L.G., Mosley-Thompson, E., Davis, M.E., Bolzan, J.F., Dai, J., Yao, T., Gundestrup, N., Wu, X., Klein, L., Xie, Z., 1989. Holocene-Late Pleistocene climatic ice core records from Qinghai-Tibetan Plateau. Science 246, 474-477.

Thompson, L.G., Yao, T., Davis, M.E., Henderson, K.A., MoslyThompson, E., Lin, P.N., Beer, J., Synal, H.A., Cole-Dai, J., Bolzan, J.F., 1997. Tropical climate instability: the Last Glacial cycle from a Qinghai-Tibetan ice core. Science 276, 1821-1825.
Van Campo, E., Cour, P., Hang, S.X., 1996. Holocene environmental changes in Bangong Co basin (western Tibet) 2. The pollen record. Palaeogeography Palaeoclimatology Palaeoecology 120, 49-63.

Wang, J., Wang, Y.J., Liu, Z.C., Li, J.Q., Xi, P., 1999. Cenozoic environmental evolution of the Qaidam Basin and its implications for the uplift of the Tibetan Plateau and the drying of central Asia. Palaeogeography Palaeoclimatology Palaeoecology 152, 37-47.

Wang, L.J., 2003. Analysis and strategies of the water table drop of reason of the Qinghai Lake. Journal of Qinghai University 21, 28-31 (in Chinese, with English Abstract).

Wang, S.M., Shi, Y.F., 1992. Perspective and discussion on late Quaternary evolution of Lake Qinghai. Journal of Lake Sciences 4, 1-8 (in Chinese, with English Abstract).

Wang, S.M., Xue, B., 1997. Environmental evolution of Zoige Basin since $900 \mathrm{ka} \mathrm{BP}$ and comparison study with Loess Plateau. Science in China Series D 40, 329-336.

Wang, Y.J., Cheng, H., Edwards, R.L., An, Z.S., Wu, J.Y., Shen, C.C., Dorale, J.A., 2001. A high-resolution absolute-dated Late Pleistocene monsoon record from Hulu Cave, China. Science 294, 2345-2348.

Wei, K., Gasse, F., 1999. Oxygen isotopes in lacustrine carbonates of West China revisited: implications for post glacial changes in summer monsoon circulation. Quaternary Science Reviews 18, 1315-1334.

Williams, D.F., Peck, J., Karabanov, E.B., Prokopenko, A.A., Kravchinsky, V., King, J., Kuzmin, M.I., 1997. Lake Baikal record of continental climate response to orbital insolation during the past 5 million years. Science 278, 1114-1117.

Williams, W.D., 1966. The relationship between salinity and $\mathrm{Sr} / \mathrm{Ca}$ in the lake water. Australian Journal of Marine and Freshwater Research 17, 169-176.

Williams, W.D., 1991. Chinese and Mongolian saline lakes: a limnological overview. Hydrobiologia 210, 39-66.

Winograd, I.J., Szabo, B.J., Coplen, T.B., Riggs, A.C., 1988. A 250,000year climatic record from Great Basin vein calcite: implications for Milankovitch theory. Science 242, 1275-1280.

Wu, J., Wang, S., Pan, H., Xia, W., 1997. Climatic variations in the past 140 ka recorded in core RM, east Qinghai-Xizang Plateau. Science in China Series D 40, 443-448.

Wu, Z., Yan, F., Mai, X., Zhu, D., Zhao, X., Wu, Z., Zhou, C., 2004. Palaeovegetation, palaeoclimate and lake-level Chang since $120 \mathrm{ka} \mathrm{BP}$ in Nam Co, central Xizang. Acta Geologica Sinica 78, 242-252.

Wunnemann, B., Chen, F.H., Riedel, F., Zhang, C.J., Mischke, S., Chen, G.J., Demske, D., Ming, J., 2003. Holocene lake deposits of Bosten Lake, southern Xinjiang, China. Chinese Science Bulletin 48, $1429-1432$

Xiao, J.L., An, Z.S., Liu, T.S., Inouchi, Y., Kumai, H., Yoshikawa, S., Kondo, Y., 1999. East Asian monsoon variation during the last 130,000 Years: evidence from the Loess Plateau of central China and Lake Biwa of Japan. Quaternary Science Reviews 18, 147-157.

Xu, H., Ai, L., Tan, L.C., An, Z.S., 2006a. Geochronology of a surface core in the northern basin of Lake Qinghai: evidence from ${ }^{210} \mathrm{~Pb}$ and ${ }^{137}$ Cs radionuclides. Chinese Journal of Geochemistry 25, 301-306.

Xu, H., Ai, L., Tan, L.C., An, Z.S., 2006b. Stable isotopes in bulk carbonates and organic matter in recent sediments of Lake Qinghai and their climatic implications. Chemical Geology 235, 262-275.

Yan, J.P., Hinderer, M., Einsele, G., 2002. Geochemical evolution of closed-basin lakes: general model and application to Lakes Qinghai and Turkana. Sedimentary Geology 148, 105-122.

Yang, B., Wang, J., Shi, Y., Braeuning, A., 2004. Evidence for a warmhumid climate in arid northwestern China during 40-30 ka BP. Quaternary Science Reviews 23, 2537-2548

Yang, H.Q., Jiang, D.X., 1965. Quaternary pollen assemblages of Lake Qinghai basin and implications. Acta Geographica Sinica 31, 321-344 (in Chinese, with English Abstract).

Yu, G., Tang, L.Y., Yang, X.D., Ke, X.K., Harrison, S.P., 2001. Modern pollen samples from alpine vegetation on the Tibetan Plateau. Global Ecology and Biogeography 10, 503-520.

Yu, J.Q., Kelts, K.R., 2002. Abrupt changes in climatic conditions across the Late-Glacial/Holocene transition on the N.E. Tibet-Qinghai 
Plateau: evidence from Lake Qinghai, China. Journal of Paleolimnology 28, 195-206.

Yuan, B.Y., Chen, K.Z., Bowler, J.M., Ye, S.J., 1990. The formation and evolution of Qinghai Lake. Quaternary Sciences, 233-243 (in Chinese, with English Abstract).

Yuan, D., Cheng, H., Edwards, R.L., Dykoski, C.A., Kelly, M.J., Zhang, M., Qing, J., Lin, Y., Wang, Y., Wu, J., Dorale, J.A., An, Z.S., Cai, Y., 2004. Timing, duration, and transitions of the Last Interglacial Asian Monsoon. Science 304, 575-578.

Zachos, J., Billups, K., Pagani, H., Sloan, L., Thomas, E., 2001. Trends, rhythms, and aberrations in global climate $65 \mathrm{Ma}$ to present. Science 292, 686-693.

Zhang, E.L., 2003. Climate and environment change during the past 1000 years in Qinghai Lake. Master Thesis, Graduate School of Chinese Academy of Sciences, PR China.

Zhang, E.L., Shen, J., Wang, S.M., Xia, W.L., Jin, Z.D., 2002a. Climate and environment change during the past 900 years in Qinghai Lake. Journal of Lake Sciences 14, 32-38 (in Chinese, with English Abstract).

Zhang, E.L., Shen, J., Xia, W.L., Zhu, Y.X., Wang, S.M., 2002b. Environmental records from organic carbon and its isotope of Qinghai Lake sediment. Marine Geology and Quaternary Geology 22, 105-108 (in Chinese, with English Abstract).

Zhang, E.L., Shen, J., Wang, S.M., Yin, Y., Zhu, Y.X., Xia, W.L., 2004. Quantitative reconstruction of the paleosalinity at Qinghai Lake in the past 900 years. Chinese Science Bulletin 49, 730-734.
Zhang, J.W., Jin, M., Chen, F.H., Battarbee, R.W., Henderson, A.C.G., 2003. High-resolution precipitation variations in the Northeast Tibetan Plateau over the last 800 years documented by sediment cores of Qinghai Lake. Chinese Science Bulletin 48, 1451-1456.

Zhang, P.X., Zhang, B.Z., Yang, W.B., 1989a. Environmental evolution of the water body of Qinghai Lake since the postglacial age. Chinese Journal of Geochemistry 8, 112-125.

Zhang, P.X., Zhang, B.Z., Yang, W.B., 1989b. On the model of postglacial palaeoclimatic fluctuation in Qinghai Lake region. Quaternary Sciences, 66-77 (in Chinese, with English Abstract).

Zhang, P.X., Zhang, P.Z., Qian, G.M., Li, H.J., Xu, L.M., 1994. The study of paleoclimatic parameter of Qinghai Lake since Holocene. Quaternary Sciences, 225-228 (in Chinese, with English Abstract).

Zhang, P.Z., Molnar, P., Downs, W.R., 2001. Increased sedimentation rates and grain sizes $2-4 \mathrm{Myr}$ ago due to the influence of climate change on erosion rates. Nature 410, 891-897.

Zhang, Q., Zhang, B.Z., 1994. The C and O isotopic compositions of ostracod shell in shallow-seated sediments and sinters in bottom of Qinghai Lake and their palaeoclimatic implications. Geochemica 23, 386-391.

Zhou, H., Zhu, Z., 2001. Oxygen isotopic composition of lacustrine carbonates since $130 \mathrm{ka}$ BP from a Tianshuihai Lake core, Tibet: an overall increasing delta ${ }^{18} \mathrm{O}$ trend and its implications. Journal of Asian Earth Sciences 20, 225-229. 